\title{
Particle hygroscopicity and its link to chemical composition in the urban atmosphere of Beijing, China, during summertime
}

\author{
Z. J. Wu ${ }^{1}$, J. Zheng ${ }^{1}$, D. J. Shang ${ }^{1}$, Z. F. Du ${ }^{1}$, Y. S. Wu ${ }^{1}$, L. M. Zeng ${ }^{1}$, A. Wiedensohler ${ }^{2}$, and M. Hu ${ }^{1}$ \\ ${ }^{1}$ State Key Joint Laboratory of Environmental Simulation and Pollution Control, College of Environmental Sciences and \\ Engineering, Peking University, Beijing 100871, China \\ ${ }^{2}$ Leibniz Institute for Tropospheric Research, 04318 Leipzig, Germany
}

Correspondence to: M. Hu (minhu@pku.edu.cn) and Z.Wu (zhijunwu@pku.edu.cn)

Received: 8 March 2015 - Published in Atmos. Chem. Phys. Discuss.: 20 April 2015

Revised: 23 December 2015 - Accepted: 18 January 2016 - Published: 1 February 2016

\begin{abstract}
Simultaneous measurements of particle number size distribution, particle hygroscopic properties, and size-resolved chemical composition were made during the summer of 2014 in Beijing, China. During the measurement period, the mean hygroscopicity parameters $(\kappa \mathrm{s})$ of $50,100,150,200$, and $250 \mathrm{~nm}$ particles were respectively $0.16 \pm 0.07,0.19 \pm 0.06,0.22 \pm 0.06,0.26 \pm 0.07$, and $0.28 \pm 0.10$, showing an increasing trend with increasing particle size. Such size dependency of particle hygroscopicity was similar to that of the inorganic mass fraction in $\mathrm{PM}_{1}$. The hydrophilic mode (hygroscopic growth factor, HGF > 1.2) was more prominent in growth factor probability density distributions and its dominance of hydrophilic mode became more pronounced with increasing particle size. When $\mathrm{PM}_{2.5}$ mass concentration was greater than $50 \mu \mathrm{g} \mathrm{m}^{-3}$, the fractions of the hydrophilic mode for 150,250 , and $350 \mathrm{~nm}$ particles increased towards 1 as $\mathrm{PM}_{2.5}$ mass concentration increased. This indicates that aged particles dominated during severe pollution periods in the atmosphere of Beijing. Particle hygroscopic growth can be well predicted using hightime-resolution size-resolved chemical composition derived from aerosol mass spectrometer (AMS) measurements using the Zdanovskii-Stokes-Robinson (ZSR) mixing rule. The organic hygroscopicity parameter $\left(\kappa_{\text {org }}\right)$ showed a positive correlation with the oxygen to carbon ratio. During the new particle formation event associated with strongly active photochemistry, the hygroscopic growth factor or $\kappa$ of newly formed particles is greater than for particles with the same sizes not during new particle formation (NPF) periods. A quick transformation from external mixture to internal mixture for pre-existing particles (for example, $250 \mathrm{~nm}$ particles)
\end{abstract}

was observed. Such transformations may modify the state of the mixture of pre-existing particles and thus modify properties such as the light absorption coefficient and cloud condensation nuclei activation.

\section{Introduction}

Particle hygroscopicity is one of the important parameters controlling direct and indirect climate effects of atmospheric particles (McFiggans et al., 2006; Haywood and Boucher, 2000). Due to water uptake, hydrophilic particles grow significantly in size at high relative humidity $(\mathrm{RH})$, which influences the particle light scattering and extinction coefficients, thereby impairing visibility (Sloane and Wolff, 1985). In addition, the water content of atmospheric aerosol particles can serve as a site for heterogeneous nucleation and reactions that perturb local photochemistry (Kreidenweis and Asa-Awuku, 2014). Therefore, a better understanding of hygroscopic behavior of atmospheric aerosol particles is required to further elucidate the physicochemical processes in the atmosphere.

The association of the particle chemical composition with their size-dependent hygroscopic behavior is rather complex. In order to overcome such complexities, Petters and Kreidenweis (2007) proposed a single hygroscopicity parameter $(\kappa)$, namely $\kappa$-Köhler theory. On the basis of the $\kappa$ Köhler theory and Zdanovskii-Stokes-Robinson (ZSR) mixing rule (Stokes and Robinson, 1966; Zdanovskii, 1948), particle hygroscopic growth of a homogeneous chemical mixture can be predicted, knowing hygroscopic growth factors of pure chemical species. Aerosol mass spectrome- 
ters (AMSs), which have been increasingly deployed in atmospheric aerosol studies, can provide a high time resolution of the size-resolved chemical composition of non-refractory particle material (DeCarlo et al., 2006). Therefore, coupled measurements of an AMS and the Hygroscopicity Tandem Differential Mobility Analyzer (H-TDMA) are able to capture highly variable changes in chemical particle composition and hygroscopicity in real time. Some studies have highlighted the advantage of using size-selected AMS information over size-averaged information from offline chemical characterization (Medina et al., 2007; Gunthe et al., 2009; Cerully et al., 2011; Wu et al., 2013).

Another key product of AMS measurements is the oxidation level and chemical information of organic aerosols. Compared to inorganic species, which exhibit a wellcharacterized hygroscopic behavior, knowledge on the influence of the water uptake of the organic aerosols remains limited (Kanakidou et al., 2005; Hallquist et al., 2009). The hygroscopicity of organic material varies with its oxidation state (Jimenez et al., 2009), which may be highly variable in the real atmosphere, depending on the history of an air mass. Such variation may present a significant challenge when predicting hygroscopicity, assuming a constant hygroscopic growth factor of the organic aerosol fraction at a given relative humidity, as has usually been done in closure studies.

More recently, some studies have been performed to investigate the relationship between particle hygroscopicity and chemical composition in both field measurements and laboratory experiments (Massoli et al., 2010; Wong et al., 2011; Lambe et al., 2011; Rickards et al., 2013; Moore et al., 2012a, b; Suda et al., 2014; Paramonov et al., 2013; Levin et al., 2012). These works specially focused on parametrizing the empirical correlations between the atomic oxygen: carbon $(\mathrm{O}: \mathrm{C})$ ratio and organic hygroscopicity parameter $(\kappa)$ derived from either hygroscopic growth factor (e.g., Wu et al., 2013; Rickards et al., 2013) or cloud condensation nuclei (CCN) activity (e.g., Mei et al., 2013; Wong et al., 2011; Lambe et al., 2011; Chang et al., 2010). Typically, a linear parametrization of the correlation between $\kappa$ and $\mathrm{O}: \mathrm{C}$ was presented. Rickards et al. (2013) recently summarized the literature data and pointed out that the systematic variability in parametrizations between organic $\kappa$ and the $\mathrm{O}: \mathrm{C}$ ratio determined from the different studies remains large. A recent work done by Suda et al. (2014) tested the influence of the number and location of molecular functional groups on the hygroscopicity of organic aerosols and may improve our understanding the mechanisms of the hygroscopicity of organics.

Over the past several decades, particle hygroscopicity measurements have been carried out worldwide, using the H-TDMA technique. Atmospheric environments, in which those measurements were performed, included marine, Antarctic, boreal forest, rural, and urban areas. Swietlicki et al. (2008) and Kreidenweis and Asa-Awu (2014) compiled the existing observations on particle hygroscopic growth in the literature. Throughout these compilations, measurements of particle hygroscopicity were rarely performed in China, which frequently experiences severe haze pollution episodes. These few particle hygroscopicity measurements using the H-TDMA technique were deployed in the Yangtze River Delta (Shanghai, Ye et al., 2013 and Hangzhou, Zhang et al., 2011), Pearl River Delta (Xinken, Cheng et al., 2008 and Hong Kong, Lopez-Yglesias et al., 2014; Yeung et al., 2014), and North China Plain (Beijing, Massling et al., 2009; Meier et al., 2009; Yufa, Achtert et al., 2009, and Wuqing, Liu et al., 2011). Unfortunately, most of the measurements lack a linkage between particle hygroscopicity and chemical composition with a high time resolution.

This study investigated the size-resolved particle hygroscopicity and chemical composition in Beijing, China, during summertime. Our work provided a general overview of particle hygroscopic behavior as well as a chemical closure study on the particle hygroscopicity using AMS-based chemical particle composition, emphasizing the organic mass fraction. Additionally, the evolution of particle hygroscopicity during the new particle formation event was investigated to understand the effects of strong photochemistry-driven atmospheric oxidation processes on particle hygroscopicity and the mixing state.

\section{Measurements}

\subsection{The sampling site}

The sampling site is on the campus of Peking University, located in northwest Beijing. The laboratory was equipped with a suite of aerosol instruments situated on the roof of a building ( $30 \mathrm{~m}$ above the ground). The relative humidity $(\mathrm{RH})$ of the sampled air was kept to below $30 \%$ using a silica gel dryer and a Nafion dryer in series. The particle number size distribution, particle hygroscopicity, and aerosol mass spectrometric measurements were made concurrently. Particle number size distributions were measured by a scanning mobility particle sizer (SMPS) spectrometer (Long Differential Mobility Analyzer (DMA) 3081 + condensation particle counter (CPC) 3775) and nano-SMPS (Nano DMA $3085+$ UCPC 3776). The sheath flow rates for nano-SMPS and SMPS were 15 and $3 \mathrm{~L} \mathrm{~min}^{-1}$, respectively. The ratio of the sample flow rate to the sheath air flow rate is $1: 10$ for both DMAs. By taking $3 \mathrm{~L} \mathrm{~min}^{-1}$ in the Long DMA, the maximum size detected is $736 \mathrm{~nm}$. The multiple charge correction, condensation particle counter (CPC) counting efficiency, and particle loss correction were carried out. Other core instruments will be briefly described below.

\subsection{Particle hygroscopicity measurements}

The H-TDMA used in this study has been described in detail in previous publications (Wu et al., 2011; Massling et al., 2003), and complied to the instrumental standards and 
quality assurance prescribed in Massling et al. (2011). The H-TDMA consists of three main parts: (1) a differential mobility analyzer (DMA1) that selects quasi-monodisperse particles, and a condensation particle counter (CPC1) that measures the particle number concentration, leaving the DMA1 at the selected particle size; (2) an aerosol humidifier conditioning the particles selected by DMA1 to a defined relative humidity (RH); (3) the second DMA (DMA2) coupled with another condensation particle counter (CPC2) to measure the number size distributions of the humidified particles. The second DMA and the aerosol humidification were placed in a temperature-controlled box. Hygroscopicity scans with $100 \mathrm{~nm}$ ammonium sulfate particles were performed every $3 \mathrm{~h}$ to analyze the stability of the relative humidity of $90 \%$ in the second DMA. Hygroscopicity scans with a deviation of more than $3 \%$ in relative humidity to the set point of $90 \%$ were not considered for further analysis.

The hygroscopic growth factor (HGF) is defined as the ratio of the particle mobility diameter, $D_{\mathrm{p}}(\mathrm{RH})$, at a given $\mathrm{RH}$ to the dry diameter, $D_{\mathrm{p}_{\mathrm{dry}}}$ :

$\operatorname{HGF}(\mathrm{RH})=\frac{D_{\mathrm{p}}(\mathrm{RH})}{D_{\mathrm{P}_{\text {dry }}}}$.

The TDMAinv method developed by Gysel et al. (2009) was used to invert the H-TDMA data. Dry scans (under $\mathrm{RH}<10 \%$ ) were used to calibrate a possible offset between DMA1 and DMA2 and define the width of the H-TDMA's transfer function (Gysel et al., 2009).

Based on the ZSR method, the HGF of a mixture can be estimated from the $\mathrm{HGF}_{i}$ of the pure components and their respective volume fractions, $\varepsilon_{i}$ (Malm and Kreidenweis, 1997):

$\mathrm{HGF}_{\text {mixed }}=\left(\sum_{i} \varepsilon_{i} \mathrm{HGF}_{i}^{3}\right)^{1 / 3}$.

Here, we assumed that two components including soluble and insoluble fractions consist of aerosols (also refer to Ehn et al., 2007; Swietlicki et al., 1999). The soluble fraction was assumed to be ammonium sulfate. Then, the water-soluble volume fraction $\left(\varepsilon_{\text {soluble }}\right)$ can be calculated by

$\varepsilon_{\text {soluble }}=\frac{\mathrm{HGF}_{\text {measured }}^{3}-1}{\mathrm{HGF}_{\left(\mathrm{NH}_{4}\right)_{2} \mathrm{SO}_{4}-1}^{3}}$,

where $\mathrm{HGF}_{\text {measured }}$ is the $\mathrm{HGF}$ of the particles measured by

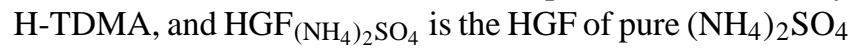
particles with the same size. When calculating $\mathrm{HGF}_{\left(\mathrm{NH}_{4} 2 \mathrm{SO}_{4}\right)}$ in different diameters, the parametrizations for $\left(\mathrm{NH}_{4}\right)_{2} \mathrm{SO}_{4}$ water activity developed by Potukuchi and Wexler (1995) and the density reported by Tang and Munkelwitz (1994) were used. The Kelvin term was considered in the calculation. In this study, the hygroscopic growth factors of 50, 100, 150,250 , and $350 \mathrm{~nm}$ particles were measured at $\mathrm{RH}=90 \%$.

\subsection{Particle chemical composition}

The Aerodyne High-Resolution Time-of-Flight AMS (HRToF-AMS, here simply referred to as AMS) (DeCarlo et al., 2006) was operated in "mass spectrum" and "particle-timeof-flight" submodes for equal time periods. Due to the $600^{\circ} \mathrm{C}$ surface temperature of the vaporizer, the AMS can only analyze the non-refractory chemical composition of the particles. Elemental carbon, crustal material, and sea salt cannot be detected. Therefore, based on the transmission efficiency of the aerodynamic lenses and the detected compounds, the AMS can provide the size-resolved chemical composition of the submicrometer non-refractory aerosol particle fraction $\left(\mathrm{NR}-\mathrm{PM}_{1}\right)$ (Canagaratna et al., 2007). Applying the method developed by Canagaratna et al. (2015), the highresolution organic particle mass spectra were used to determine the elemental composition and the oxygen to carbon atomic ratio $(\mathrm{O}: \mathrm{C})$. The vacuum aerodynamic diameter for AMS measurements was converted to the particle mobility diameter by division of the AMS vacuum aerodynamic diameter by the estimated particle density. Here, particle density was estimated by comparing mass-diameter distributions, derived from the AMS measurements, and the particle volume distributions, calculated from the SMPS measurements. This method was used in Kostenidou et al. (2007). Here, we assume that the particles detected with a shape factor of 1 are spherical. The particle volume size distribution is calculated from particle number size distribution. The optimized particle effective density is $1520 \mathrm{~kg} \mathrm{~m}^{-3}$. Hereafter, the mobility diameter (assuming spherical particles) was used for AMS data below.

AMS positive matrix factor (PMF) analysis was performed to identify different factors of organic aerosols (OAs) on the basis of the high-resolution mass spectra of organics (Ulbrich et al., 2009). Four OA components were resolved by PMF, including low-volatility oxygenated organic aerosol (LV-OOA), semi-volatile oxygenated OA (SV-OOA), hydrocarbon-like OA (HOA), and cooking OA (COA). LVOOA and SV-OOA typically represented aged secondary organic aerosols (SOAs) and freshly formed SOAs, respectively (Ulbrich et al., 2009). HOA and COA were both anthropogenic primary organic aerosol (POA) components (Lanz et al., 2007).

Black carbon (BC) mass concentration in $\mu \mathrm{g} \mathrm{m}^{-3}$ is derived from Photoacoustic Extinctiometer (PAX) measurements (DMT company) (Arnott et al., 1999) equipped with a $\mathrm{PM}_{1}$ cut-off inlet. In this study, PAX measurements were performed at a wavelength of $532 \mathrm{~nm}$. Before carrying out the PAX measurements, the device was calibrated carefully using lab-generated monodisperse polystyrene latex (PSL) particles and polydisperse propane soot particles. The calibration curves were used to correct the measured scattering and absorption coefficients. 


\subsection{Meteorological parameters}

Additionally, a weather station (Met One Instruments Inc.) provided the meteorological parameters. The wind speed, wind direction, ambient temperature, and relative humidity $(\mathrm{RH})$ were detected.

Air mass backward trajectories arriving at the sampling site were calculated using the NOAA HYSPLIT-4 (Hybrid Single-Particle Lagrangian Integrated Trajectory) model (Draxler and Hess, 1998). The $48 \mathrm{~h}$ trajectories terminated on a height of $200 \mathrm{~m}$ above the ground at 00:00, 06:00, 12:00, and 18:00 LT (local time) (UTC+08). In total, 100 air mass backward trajectories were grouped by assigning them to five clusters using a $k$-means clustering algorithm. The number of clusters was identified according to the changes of total spatial variance (cf. HYSPLIT4 user's guide). Five was chosen as the final number of clusters considering optimum separation of trajectories (larger number of clusters) and simplicity of display (lower number of clusters).

\section{Theory}

\subsection{Hygroscopicity parameter}

The hygroscopicity parameter, $\kappa$, can be calculated from the hygroscopic growth factor (HGF) measured by H-TDMA (Petters and Kreidenweis, 2007):

$\kappa_{\text {HTDMA }}=\left(\mathrm{HGF}^{3}-1\right)\left(\frac{\exp \left(\frac{A}{D_{P_{\mathrm{dry}}} \cdot \mathrm{HGF}}\right)}{\mathrm{RH}}-1\right)$

$A=\frac{4 \sigma_{\mathrm{s} / \mathrm{a}} M_{\mathrm{w}}}{R T \rho_{\mathrm{w}}}$,

where $D_{P_{\text {dry }}}$ and HGF are the initial dry particle diameter and the hygroscopic growth factor at $90 \% \mathrm{RH}$ measured by H-TDMA, respectively. $\sigma_{\mathrm{s} / \mathrm{a}}$ is the droplet surface tension (assumed to be that of pure water, $\sigma_{\mathrm{s} / \mathrm{a}}=0.0728 \mathrm{~N} \mathrm{~m}^{-2}$ ), $M_{\mathrm{w}}$ the molecular weight of water, $\rho_{\mathrm{w}}$ the density of liquid water, $R$ the universal gas constant, and $T$ the absolute temperature.

For a given internal mixture, $\kappa$ can also be predicted by a simple mixing rule on the basis of chemical volume fractions $\varepsilon_{i}$ (Petters and Kreidenweis, 2007):

$\kappa_{\mathrm{chem}}=\sum_{i} \varepsilon_{i} \kappa_{i}$.

Here, $\kappa_{i}$ and $\varepsilon_{i}$ are the hygroscopicity parameters and volume fraction for the individual (dry) components in the mixture with $i$, the number of components in the mixture. We derived $\varepsilon_{i}$ from the particle chemical composition measured by AMS and PAX. The detailed description of how to calculate volume fraction is given in Sect. 3.2. In the following discussions, $\kappa_{\mathrm{HTDMA}}$ and $\kappa_{\text {chem }}$ denote the values derived from H-TDMA and predicted using the ZSR mixing rule, respectively.

\subsection{Hygroscopicity-chemical composition closure}

The AMS provided the particle mass size distribution of sulfate $\left(\mathrm{SO}_{4}^{2-}\right)$, nitrate $\left(\mathrm{NO}_{3}^{-}\right)$, and ammonium $\left(\mathrm{NH}_{4}^{+}\right)$ions as well that of organic compounds. We used a simplified ion pairing scheme as presented in Gysel et al. (2007) to convert the ion mass concentrations to the mass concentrations of their corresponding inorganic salts as listed in Table 1. Unlike inorganic salts, the hygroscopicity of organic aerosols is not well recognized. In the literature, there were different approaches in representing $\kappa_{\text {org }}$ in the closure studies. Typically, $\kappa_{\text {org }}$ is assumed as a constant value. Chang et al. (2010) represented $\kappa_{\text {org }}$ by using the factors from the PMF analysis to group organics measured by AMS into two components: a non-hygroscopic, unoxygenated component consisting of the hydrocarbon-like organic aerosol (HOA) factor and a hygroscopic component, consisting of the oxygenated factors LV-OOA, SV-OOA, and biomass burning organic aerosol (BBOA). In our study, organic materials derived from AMS measurements were grouped into two components including secondary organic aerosols (SOAs) and primary organic aerosols (POAs) based on AMS-PMF analysis. SOA, including LV-OOA and SV-OOA factors, is a more oxygenated organic aerosol, thereby more hygroscopic, and has a $\kappa_{\mathrm{SOA}}$ of 0.1 , which was calculated from the hygroscopic growth factor of organics at $\mathrm{RH}=90 \%$ as given in Gysel et al. (2007) using Eq. (4) in Sect. 3.1. The $\kappa$ s, which range from 0.06 up to 0.2 , with a bin width of 0.02 were selected for testing the closure in our study. By taking $\kappa_{\mathrm{SOA}}=0.1$, the slope of the linear curve fit is closest to 1 . Therefore, $\kappa_{\mathrm{SOA}}=0.1$ was chosen to perform the closure between $\kappa_{\text {HTDMA }}$ and $\kappa_{\text {chem }}$. One should note that $\kappa$ of SOA may have varied with its oxidation state (Jimenez et al., 2009). The usage of a constant $\kappa$ value may introduce uncertainty in the closure of particle hygroscopicity and chemical composition. POA is the unoxygenated component consisting of the HOA and COA factors and is treated as hydrophobic material with $\kappa_{\mathrm{POA}}=0$. Then, $\kappa_{\text {org }}$ can be calculated as

$k_{\mathrm{Org}}=f_{\mathrm{POA}} \cdot k_{\mathrm{POA}}+f_{\mathrm{SOA}} \cdot k_{\mathrm{SOA}}$.

Here, $\kappa_{\text {org }}$ is overall $\kappa$ for organic aerosols. $f_{\mathrm{POA}}$ and $f_{\text {SOA }}$ are volume fractions of POA and SOA in total organic aerosols measured by the AMS. One should note that Sun et al. (2012b) found that the contributions of POA and SOA to OA showed a size dependency in an urban environment. The relative contribution of POA to OA significantly increased with decreasing particle sizes. In this study, the closure studies were performed for particles with the mobility diameters of 150,250 , and $350 \mathrm{~nm}$ (larger than $200 \mathrm{~nm}$ in vacuum aerodynamic diameter). Using the relative contribution of POA to OA in $\mathrm{PM}_{1}$ tended to overestimate the percentage of POA for the size range focused in this study, thus underestimate the $\kappa$. In our case, the POA/OA and SOA/OA were 0.39 and 0.61 , respectively. According to Eq. (7), the $\kappa_{\text {org }}$ can be calculated as 0.06 , assuming $\kappa_{\mathrm{SOA}}=0.1$. On the basis of 
Table 1. Gravimetric densities $(\rho)$ and hygroscopicity parameters $(\kappa \mathrm{s})$ used in this study.

\begin{tabular}{lcccccc}
\hline Species & $\mathrm{NH}_{4} \mathrm{NO}_{3}$ & $\mathrm{NH}_{4} \mathrm{HSO}_{4}$ & $\left(\mathrm{NH}_{4}\right)_{2} \mathrm{SO}_{4}$ & $\mathrm{SOA}$ & $\mathrm{POA}$ & $\mathrm{BC}$ \\
\hline$\left(\mathrm{kg} \mathrm{m}^{-3}\right)$ & 1720 & 1780 & 1769 & 1400 & 1000 & 1700 \\
$\kappa$ & 0.58 & 0.56 & 0.48 & 0.1 & 0 & 0 \\
\hline
\end{tabular}

Sun et al. (2012b)'s study, the POA/OAs for 150, 250, and $350 \mathrm{~nm}$ particles were $0.30,0.23$, and 0.19 , respectively. Using these ratios and Eq. (7), the calculated $\kappa_{\text {org }}$ s were 0.07 , 0.08 , and 0.08 , respectively, which were slightly higher than the one $\left(\kappa_{\text {org }}=0.06\right)$ in our case. This minor difference can be negligible.

The volume fraction of each species was calculated from the particle mass concentration divided by its density as given in Table 1. The densities for inorganic salts were well defined. By summarizing the articles published (Park et al., 2004; McMurry et al., 2002; Kondo et al., 2011; Kiselev et al., 2010), $1700 \mathrm{~kg} \mathrm{~m}^{-3}$ was selected as BC density. The hygroscopicity parameter $\kappa$ of the hydrophobic black carbon was considered to be zero. The density of SOA was taken to be $1400 \mathrm{~kg} \mathrm{~m}^{-3}$ (Gysel et al., 2007; Alfarra et al., 2006; Dinar et al., 2006). The density for POA is chosen as $1000 \mathrm{~kg} \mathrm{~m}^{-3}$, since POA is thought to be similar to lubricating oil. The $\kappa_{\text {HTDMA }}$ values for the individual compounds listed in Table 1 were calculated from the hygroscopic growth factor at $90 \% \mathrm{RH}$ as given in Gysel et al. (2007) using Eq. (4) in Sect. 3.1.

One should note that mineral dust (e.g., Shao et al., 2007) and sea salt (Clarke et al., 2006) can extend into the submicron range. Due to sea salt and dust, particles cannot be detected by AMS; neglecting dust and sea salt may introduce bias in the closure between particle hygroscopicity and chemical composition. Neglecting sea salt particles with a high hygroscopicity growth $\left(\kappa_{\mathrm{NaCl}}=1.12\right.$ at $90 \%$, Petters and Kreidenweis, 2007) may cause an underestimation of particle hygroscopicity. Inversely, neglecting mineral dust with less hygroscopicity (mineral dust $\kappa=0.01-0.08$, Koehler et al., 2009) may cause an overestimation of particle hygroscopicity. The statistical analyses on the basis of a long-term observation showed that the dust storm events typically take place in the spring in Beijing (Wu et al., 2009). In this study, the measurements were carried out during summertime. Meanwhile, no dust storm events were observed. The sea salt is not a major source of atmospheric particles (e.g., Song et al., 2007) because Beijing is not a coastal city. Therefore, the uncertainties in hygroscopicity-chemical composition closure caused by neglecting mineral dust and sea salt might be ignored.

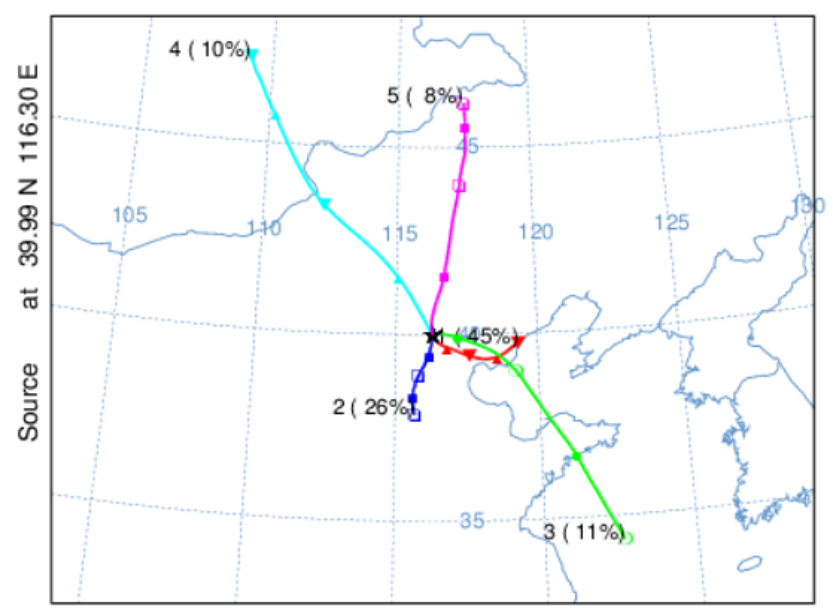

Figure 1. Mean air mass backward trajectories for five clusters arriving at the sampling site.

\section{Results and discussion}

\subsection{Meteorological conditions during the sampling period}

Figure 1 showed the mean air mass backward trajectories for five clusters arriving at the sampling site from 31 May to 24 June 2014. The mean backward trajectories in five clusters showed the significant differences in direction and length. The air masses from the east $(45 \%)$ and the south $(26 \%)$ were the dominate trajectories. The short-length air mass backward trajectories in cluster 1 and 2 indicated that air parcels moved slowly and spent much more time over the industrialized regions south and east of Beijing. As a result, the southerly and easterly air masses may be heavily polluted once they arrived at Beijing (Wehner et al., 2008). Cluster 3 spent much more time over the sea and may be associated with humid air masses. Northerly $(8 \%)$ and northwesterly (10\%) air masses, as represented by clusters $4-5$, typically lead to the advection of dry and continental air into the Beijing area.

Figure 2 displays the time series of wind speed, wind direction, ambient temperature, and RH during the sampling period. There was a clear diurnal cycle for all meteorological parameters. During nighttime, the wind speed was usually very low (around $1 \mathrm{~m} \mathrm{~s}^{-1}$ ) and started to increase around noon on each day. The nighttime static wind may lead to very poor dilution with clean air and dispersion of pollutants and 


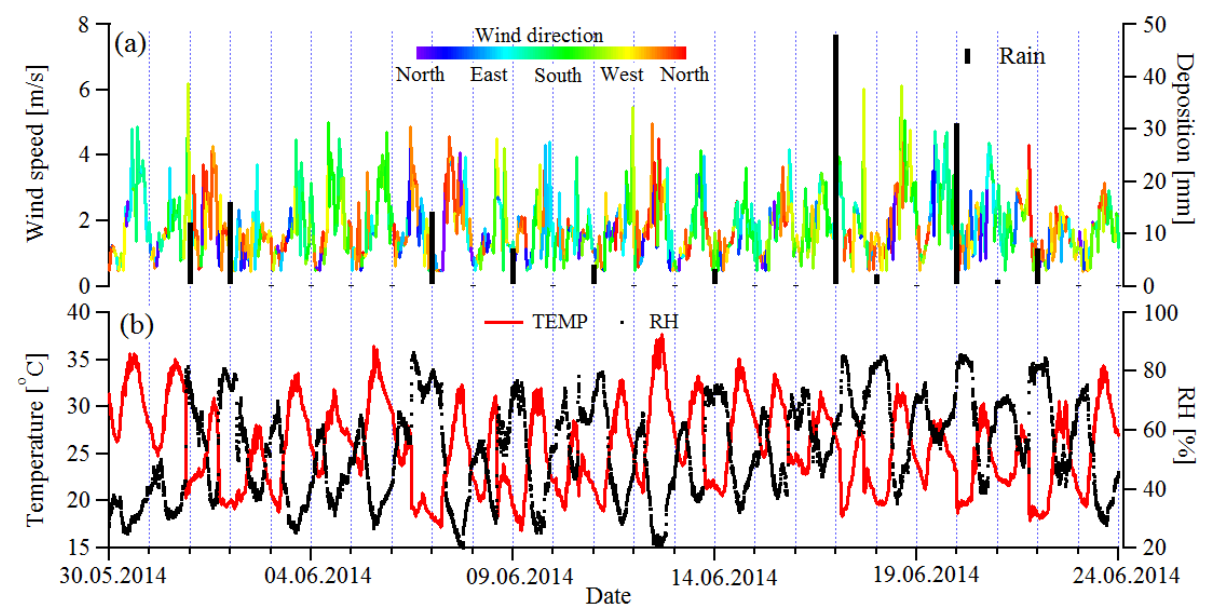

Figure 2. Time series of wind speed, wind direction, wet deposition (a) and temperature and RH (b) during the sampling period.
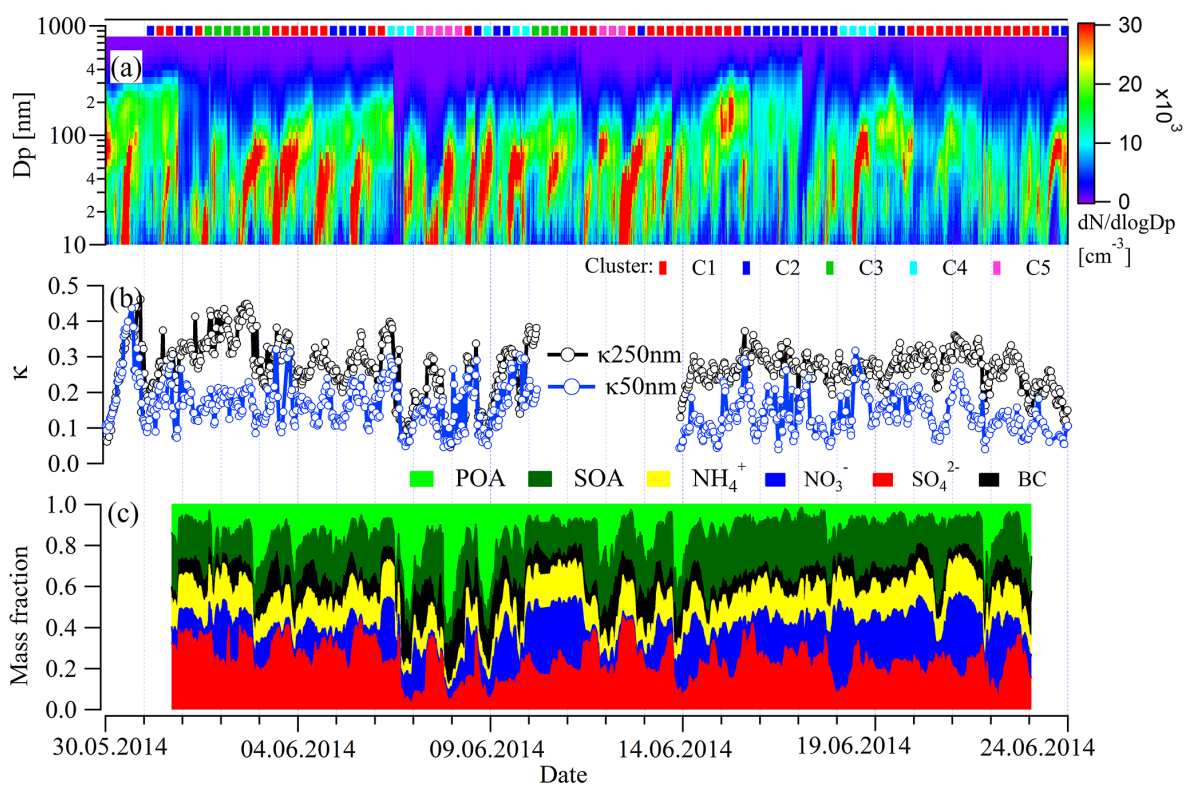

Figure 3. Time series of particle number size distribution (a), hygroscopicity parameter $(\kappa)(\mathbf{b})$, and chemical composition of $\mathrm{PM}_{1}(\mathbf{c})$ during the measuring period. The color bars in the upper panel (a) indicate the trajectory clusters. $\mathrm{C} 1-\mathrm{C} 5$ represent five trajectory clusters.

result in the local emissions were trapped in the urban atmosphere. The ambient temperature usually was above $30^{\circ} \mathrm{C}$ during daytime and around $20^{\circ} \mathrm{C}$ during nighttime. The average temperature and $\mathrm{RH}$ were $24 \pm 7{ }^{\circ} \mathrm{C}$ and $45 \pm 20 \%$, respectively. It rained several times during the measuring period, as indicated in Fig. 2a. The heaviest wet deposition occurred on 17 June. The wet deposition obviously removed the atmospheric particles, as can be seen from the particle number size distribution shown in Fig. 3a.

In summer, the new particle formation and traffic emissions are the major sources of ultrafine particles in the atmosphere of Beijing (Wu et al., 2007, 2008). In addition, air masses across the industrialized regions in the south and east typically bring high concentrations of accumulation-mode particles to urban areas of Beijing (Wehner et al., 2008).

\subsection{Overview of particle hygroscopic growth and the mixing state}

Figure 3 provides an overview of the particle number size distribution (Fig. 3a), hygroscopicity parameter ( $\kappa$ ) (Fig. 3b), and chemical composition of $\mathrm{PM}_{1}$ (Fig. 3c) during the entire field campaign. The trajectory clusters were marked as black circles in Fig. 3a. As shown in Fig. 3a, new particle formation (NPF) events were observed frequently. During the sampling period, the inorganic species and SOA dominated in NR-PM $M_{1}$ when air masses came from the south and east of 


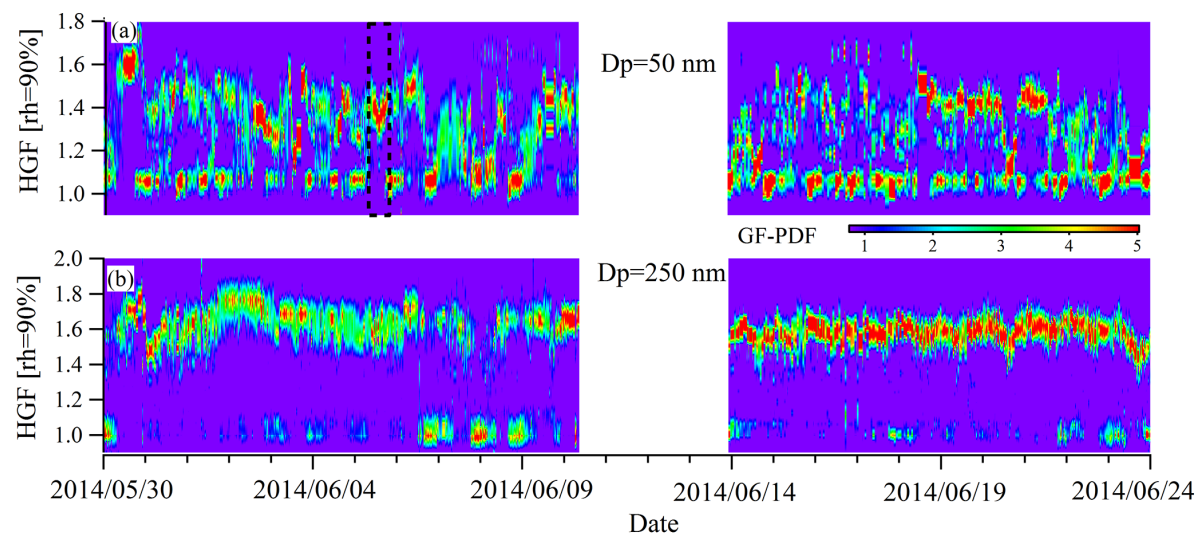

Figure 4. The time series of the GF-PDFs for 50 and $250 \mathrm{~nm}$ particles.
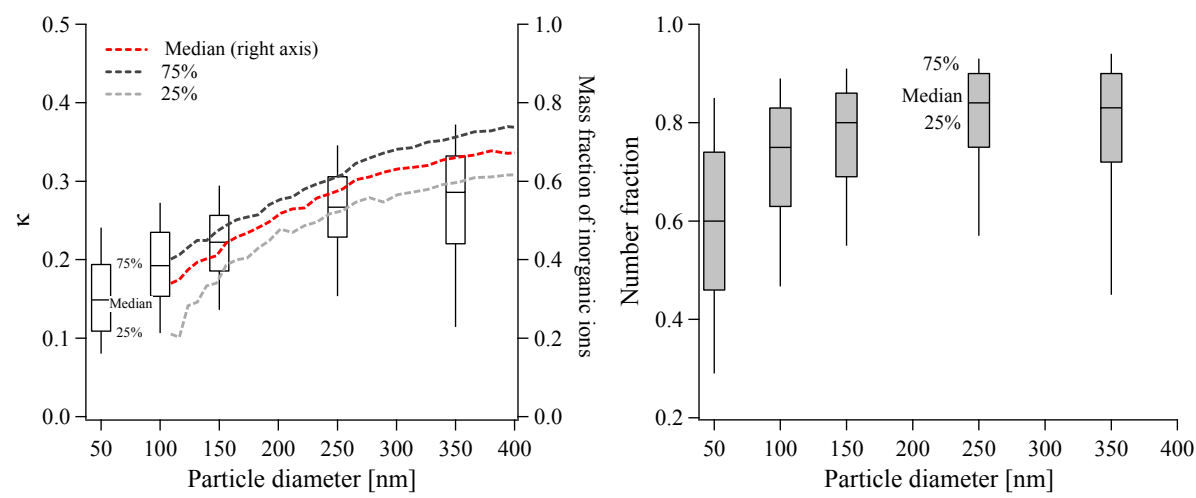

Figure 5. Size-resolved particle hygroscopicity and inorganic mass fraction (left panel) in NR-PM 1 and the size-dependent number fraction of the hydrophilic mode (right panel).

Beijing (trajectory cluster 1 and 2 as indicated by black circles in Fig. 3a). SOA usually dominated in the organic compounds during the sampling period. Differently, the POA was a major fraction on 7,8, and 9 June, when the BC mass fraction increased too. During this time period, the northerly air masses (trajectory cluster 5 marked in Fig. 3a) arriving at the measurement site may be influenced by wheat straw burning, which usually takes place from late May to early June over the North China Plain. Several previous studies have shown that wheat straw burning significantly contributes to the degradation of air quality in Beijing during the harvest season in the summer (Li et al., 2008; Zheng et al., 2005).

Figure $3 \mathrm{~b}$ displays the time series of hygroscopicity parameters for $50 \mathrm{~nm}\left(\kappa_{50} \mathrm{~nm}\right)$ and $250 \mathrm{~nm}\left(\kappa_{250 \mathrm{~nm}}\right)$ particles. Both $\kappa_{50 \mathrm{~nm}}$ and $\kappa_{250 \mathrm{~nm}}$ had an obvious temporal variability. Their variations were similar to that of inorganic mass fraction in $\mathrm{PM}_{1}$ displayed in Fig. 3c. An in-depth analysis of the relationship between particle hygroscopicity and chemical composition will be given in Sect. 4.3. Figure 4 gives an overview of growth factor probability density functions (GFPDFs) for 50 and $250 \mathrm{~nm}$ particles during the entire field campaign. The GF-PDFs of both 50 and $250 \mathrm{~nm}$ showed two distinct modes, which are identified as hydrophobic mode $(\mathrm{GF}<1.2)$ and hydrophilic mode $(\mathrm{GF}>1.2)$. This implied that the particles were usually externally mixed. The hydrophilic mode of $250 \mathrm{~nm}$ particles is more prominent most of the time. Differently, the hydrophobic mode dominated in $50 \mathrm{~nm}$ particles. As marked in Fig. 4a by the square with dashed lines, the hydrophobic mode disappeared occasionally, indicating that the vast majority of particles in this size range can be fully hygroscopic. This phenomenon took place during the NPF events. A case study of particle hygroscopic behavior during the NPF event will be given in Sect. 4.4.

Figure 5 (left panel) shows the size-dependent particle hygroscopicity parameters and inorganic mass fraction of NR$\mathrm{PM}_{1}$ derived from averaging over the entire measuring period. The particle hygroscopicity increased with increasing particle size, displaying the same size dependency with the mass fraction of inorganic composition in NR-PM $\mathrm{PM}_{1}$. This is because inorganics, including ammonium sulfate and ammonium nitrate, are major water-soluble chemical compounds in the atmospheric particles. Compared to inorganic components, the hygroscopicity parameter of organic aerosols is typically lower than 0.1 in the ambient atmosphere (Varut- 
bangkul et al., 2006; Virkkula et al., 1999). A similar size dependency of particle hygroscopicity was observed in various environments. For examples, Levin et al. (2012, 2014) and Paramonov et al. (2013) reported that particle hygroscopicity increased with particle size at a forested site in Colorado and a boreal environment of southern Finland at the SMEAR station, respectively. Jurányi et al. (2013) observed that particle hygroscopic growth increased with increasing dry diameter in the urban areas of Paris. Swietlicki et al. (2008) compiled worldwide H-TDMA data and found that the particle hygroscopicity showed a pronounced size dependency, with hygroscopicity increasing with particle diameter.

Figure 5 (right panel) shows the size dependency of the fraction of the hydrophilic mode. It can be seen that the hydrophilic mode was more prominent, no matter what particle size was considered. With increasing particle size, the dominance of hydrophilic mode became more pronounced. Above $150 \mathrm{~nm}$, the number fraction of hydrophilic mode was around 0.8 , and its size dependency was insignificant. Below $150 \mathrm{~nm}$, the number fraction of hydrophilic mode increased significantly with increasing particle size. The median number fraction of hydrophilic mode for $50 \mathrm{~nm}$ particles was 0.6 , which was smaller than that of larger particles. Fors et al. (2011) also reported that smaller particles had a higher fraction of less hygroscopic particles in southern Sweden. Larger particles (here, above $150 \mathrm{~nm}$ ) constituting a larger fraction of the hydrophilic mode can be explained as such: in the urban area, traffic emissions are major sources for particles below $100 \mathrm{~nm}$. Typically, freshly emitted particles, such as soot, are initially hydrophobic and externally mixed. In contrast, larger particles have undergone atmospheric aging processes during transport (such as coagulation, condensation, chemical reactions) (Pöschl, 2005) for a longer time. These aging processes enhance the particle's water solubility (Pöschl, 2005; Jimenez et al., 2009) and result in more internally mixed particles.

Over the entire study, the mean $\kappa \mathrm{s}$ of $50,100,150$, 250 , and $350 \mathrm{~nm}$ particles were $0.16 \pm 0.07,0.19 \pm 0.06$, $0.22 \pm 0.06,0.26 \pm 0.07$, and $0.28 \pm 0.10$, respectively. These values were similar to the hygroscopicity parameter $\kappa=0.12-0.27$ (measured at $\mathrm{RH}=90 \%$ ) for $35-265 \mathrm{~nm}$ determined in the urban atmosphere of Paris (Jurányi et al., 2013). Yeung et al. (2014) observed that hygroscopicity $\kappa \mathrm{s}$ of particles with sizes of $75,100,150$, and $200 \mathrm{~nm}$ were respectively $0.28,0.29,0.26$, and 0.27 when Hong Kong experienced a continental airstream. In their study, the particle hygroscopicity showed no obvious size dependency and was higher than our observation in Beijing. In contrast, $\kappa \mathrm{s}$ measured were relatively low at a forested site in Colorado $(\kappa=0.16 \pm 0.08$ detected by $\mathrm{CCN}$ counter $(\mathrm{CCNc})$ ), a boreal forest in Finland ( $\kappa=0.18$ at RH $=90 \%$ ) (Sihto et al., 2011), and a tropical forest site in the Amazon $(\kappa=0.16 \pm 0.06 \mathrm{de}-$ tected by $\mathrm{CCNc}$ ) (Gunthe et al., 2009). At these forested locations, organic species were predominant in particles. Dif-

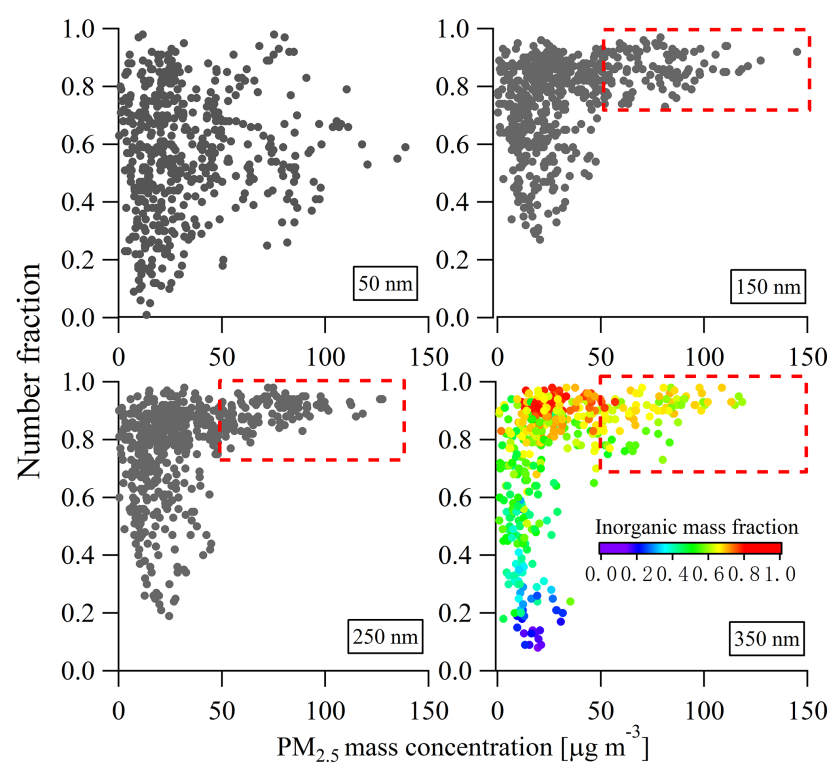

Figure 6. Number fraction of the hydrophilic mode vs. $\mathrm{PM}_{2.5}$ mass concentration. For $350 \mathrm{~nm}$ particles, the number fraction is colored by the inorganic mass fraction (sulfate + nitrate + ammonium) in $\mathrm{PM}_{1}$.

ferently, in the atmosphere of Beijing, particles were dominated by the inorganic fraction, as shown in Fig. 3c.

The haze issue caused by high aerosol loadings over the North China Plain is a major concern, for both air quality and climate effects. Here, the $\mathrm{PM}_{2.5}$ mass concentration, which was measured by the TEOM ${ }^{\circledR}$ Monitor (Series 1400ab), and which is a key factor characterizing air pollution, is plotted against the number fraction of the hydrophilic mode (Fig. 6) to analyze the relationship between the particle mixing state and air pollution. There was no obvious dependency between the $\mathrm{PM}_{2.5}$ mass concentration and the number fraction of hydrophilic mode for $50 \mathrm{~nm}$ particles, which can be expected due to the low mass fraction of ultrafine particles. This was however also true for 150,250 , and $350 \mathrm{~nm}$ particles, if $\mathrm{PM}_{2.5}$ mass concentration is lower than $50 \mu \mathrm{g} \mathrm{m}^{-3}$. The reason for this is that the particle mass concentration is dominated by local sources and less by secondary aerosol particles formed during long-range transport. Conversely, when $\mathrm{PM}_{2.5}$ mass concentration was larger than $50 \mu \mathrm{g} \mathrm{m}^{-3}$, the fraction of the hydrophilic mode was larger than 0.7. With the increasing $\mathrm{PM}_{2.5}$ mass concentration, the fraction rose towards 1 , indicating that the aged aerosols were dominant. This means that secondary aerosol particles were dominant during severe particulate pollution episodes, occurring frequently in Beijing. Our results were consistent with recent scientific findings (Guo et al., 2014; Huang et al., 2014) which have pointed out that the haze pollution events were mainly attributable to secondary aerosol formation. As an example, the number fraction of the hydrophilic mode was colored by the inorganic $\left(\mathrm{SO}_{4}^{2-}+\mathrm{NO}_{3}^{-}+\mathrm{NH}_{4}^{+}\right)$mass fraction in $\mathrm{PM}_{1}$ in 
Fig. 6. Clearly, the inorganic mass fraction spanned from 0.1 up to 0.8 associating with an increasing number fraction of hydrophilic mode. When $\mathrm{PM}_{2.5}$ mass concentration is larger than $50 \mu \mathrm{g} \mathrm{m}^{-3}$, the inorganic mass fraction ranged from 0.5 to 0.7 . This indicates that both inorganic and organic species played key roles in leading to the particle aging. The contribution of inorganic material is slightly higher than that of organic compounds.

\subsection{Closure between particle hygroscopicity and chemical components}

The AMS-derived particle mass concentrations for different chemical compounds were used to perform a closure study with hygroscopicity of 150,250 , and $350 \mathrm{~nm}$ particles. The particle mass concentrations for individual species were integrated over the size interval of $D_{P_{\text {dry }}} \pm 50 \mathrm{~nm}$. Here, $D_{P_{\text {dry }}}$ is the dry particle diameter selected by H-TDMA. Considering the limited signal statistics in this narrow size range, AMS data were used to carry out the closure only if the sum of sulfate, nitrate, ammonium, and organics mass concentrations, derived from integrating a size range of $D_{P_{\mathrm{dry}}} \pm 50 \mathrm{~nm}$, was greater than $1 \mu \mathrm{g} \mathrm{m}^{-3}$.

The $\mathrm{BC}$ particle mass concentration within the size range of $D_{P_{\text {dry }}} \pm 50 \mathrm{~nm}$ was estimated as follows: first, the ratio $\left(R_{\mathrm{BC} / \mathrm{PM}_{1}}\right)$ of $\mathrm{BC}$ particle mass concentration (derived from PAX) to bulk particle mass concentration (derived from AMS measurement) was calculated, assuming this ratio was independent of the particle size. Afterwards, the BC particle mass concentration in a certain size range, e.g., $150 \pm 50 \mathrm{~nm}$, was estimated by multiplying the mass concentration derived from integrating a particle size range of $150 \pm 50 \mathrm{~nm}$ (AMS data) and $R_{\mathrm{BC} / \mathrm{PM}_{1}}$. One should note that this assumption may give an uncertainty in the closure, because the $\mathrm{BC}$ mass concentration has a dependency on particle size (Huang et al., 2006). Sun et al. (2012a) reported that the average mass size distribution of $\mathrm{BC}$ had one mode peaking at a volumeequivalent diameter of $207 \mathrm{~nm}$. The sizes of $150,250,350 \mathrm{~nm}$ covered the peak of $\mathrm{BC}$ mass size distribution. As a result, the $\mathrm{BC}$ mass concentration for particles in diameter of 150 , 250 , and $350 \mathrm{~nm}$ should be higher than that estimated with the assumption of uniformly distributed $\mathrm{BC}$ across the whole particle size range. We should note that Sun et al. (2012a)'s measurements were performed in the summer of 2012. The soot size distribution in 2012 might be different from our measurements. Considering that the weather conditions and source emissions during summertime are typically similar in different years in Beijing, the BC size distributions measured in 2012 are considered as being representative.

The SOA and POA mass fractions within the size range of $D_{P_{\mathrm{dry}}} \pm 50 \mathrm{~nm}$ were estimated using a similar method as the calculation of $\mathrm{BC}$ mass concentration given above. The POA $\left(\mathrm{MF}_{\mathrm{POA}}\right)$ and $\mathrm{SOA}\left(\mathrm{MF}_{\mathrm{SOA}}\right)$ mass fractions in total organic aerosols in NR-PM 1 are calculated on a basis of the AMS-PMF analysis results. Assuming $\mathrm{MF}_{\mathrm{POA}}$ and $\mathrm{MF}_{\mathrm{SOA}}$

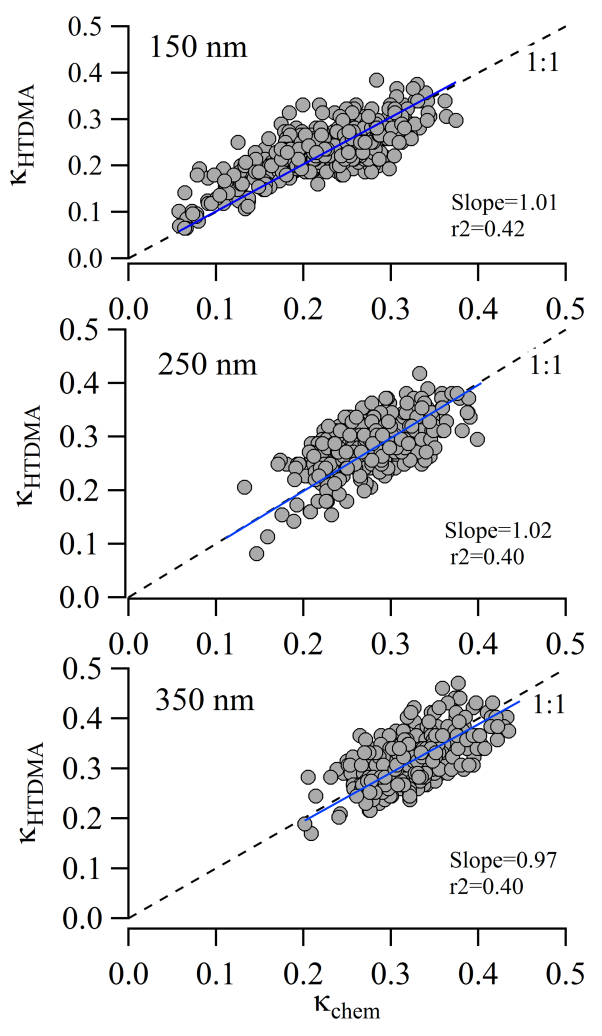

Figure 7. $\kappa_{\text {HTDMA }}$ vs. $\kappa_{\text {chem }}$ using size-resolved chemical composition data. All the root-mean-square errors (RMSEs) of the linear fits were 0.04 .

were independent of the particle diameter, the POA or SOA mass concentration in the size range $D_{P_{\mathrm{dry}}} \pm 50 \mathrm{~nm}$ can be calculated by multiplying the organic mass concentration derived from integrating a particle size range of $150 \pm 50 \mathrm{~nm}$

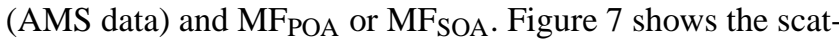
tering plots of $\kappa_{\text {chem }}$ calculated from the size-resolved chemical composition against $\kappa_{\text {HTDMA }}$. The fitted slopes for 150 , 250 , and $350 \mathrm{~nm}$ particles were $1.01,102$, and 0.97 , respectively. All the root-mean-square errors (RMSEs) of these linear fits were 0.04 . This indicates that the measured $\kappa$ can be well predicted on the basis of AMS data and the ZSR mixing rule, while one should note that the assumption of the $\mathrm{BC}$ mass size distribution and $\kappa_{\text {org }}$ value in the closure, as well as the measurement uncertainties for both H-TDMA and AMS, could introduce biases in the closure. This may lead to a scatter of datapoints around the line of fit.

Assuming the inorganic fraction was fully explained by the ZSR mixing rule, $\kappa_{\text {org }}$ can be calculated by subtracting $\kappa$ of inorganic fraction and BC from $\kappa_{\mathrm{HTDMA}}$. Here, $\kappa_{\mathrm{org}}$ for $150 \mathrm{~nm}$ particles was calculated because it provided a better closure result and higher organic fraction in contrast to other particle sizes. Duplissy et al. (2011) pointed out that the uncertainty in the estimation of $\kappa_{\text {org }}$ decreases with increasing organic fraction; thereby, only data featuring organic fractions larger than $50 \%$ were used in this calculation. In addi- 


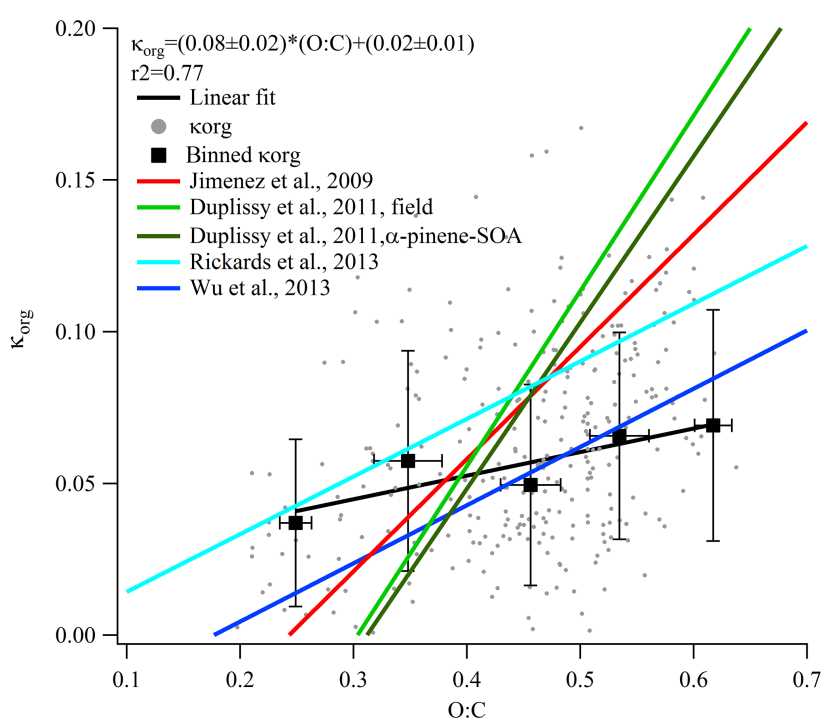

Figure 8. The relationship between the organic hygroscopicity parameter $\left(\kappa_{\mathrm{org}}\right)$ and oxygen to carbon ratio $(\mathrm{O}: \mathrm{C})$. In this figure, the $\mathrm{O}: \mathrm{C}$ ratios determined by applying the method developed by Aiken et al. (2008) are used to consider the comparability between this study and others.

tion, the evaporation of $\mathrm{NH}_{4} \mathrm{NO}_{3}$ could occur in the DMAs and the humidification section. This leads to a positive prediction bias because the volatile $\mathrm{NH}_{4} \mathrm{NO}_{3}$, which is fully detected by AMS, can evaporate in the H-TDMA system (Gysel et al., 2007). Here, only data with $\mathrm{NH}_{4} \mathrm{NO}_{3}$ volume fraction below $20 \%$ were considered in order to reduce the evaporation artifact of $\mathrm{NH}_{4} \mathrm{NO}_{3}$. Restricting data to times when ammonium nitrate is below $20 \%$ and organics were greater than $50 \%$ may lead to a bias in datapoints between daytime and nighttime. The statistics showed that there were more nighttime datapoints (204 datapoints) than those during daytime (160 datapoints). This is because the organic mass fraction during nighttime was higher than that during daytime. This bias could make the fit between $\kappa_{\text {org }}$ and $\mathrm{O}: \mathrm{C}$ ratio more representative for nighttime situations than daytime.

Figure 8 shows $\kappa_{\text {org }}$ as a function of the $\mathrm{O}: \mathrm{C}$ ratio. With regards to the scattering point, $\kappa_{\text {org }}$ was not correlated to the $\mathrm{O}: \mathrm{C}$ ratio. Several previous studies have reported the similar plots of $\kappa_{\text {org }}$ values as a function of O : C ratios (Chang et al., 2010; Bhattu and Tripathi, 2015; Rickards et al., 2013). In order to derive an empirical relationship between $\kappa_{\text {org }}$ and $\mathrm{O}: \mathrm{C}$ ratios, $\kappa_{\text {org }}$ values were usually binned by $\mathrm{O}: \mathrm{C}$ in increments of 0.1. As displayed in Fig. 8, a linear fitting function $\left(\kappa_{\mathrm{org}}=(0.08 \pm 0.02) \cdot \mathrm{O}: \mathrm{C}+(0.02 \pm 0.01)\right)$ was obtained. Some empirical functions reported by other previous studies are also shown in Fig. 8. In these previous studies (Wu et al., 2013; Jimenez et al., 2009; Rickards et al., 2013; Duplissy et al., 2011), the $\kappa_{\text {org }}$ values were derived from the measurements performed in the subsaturation regime. In Massoli et al.'s (2010) study (not shown in Fig. 8 due to the

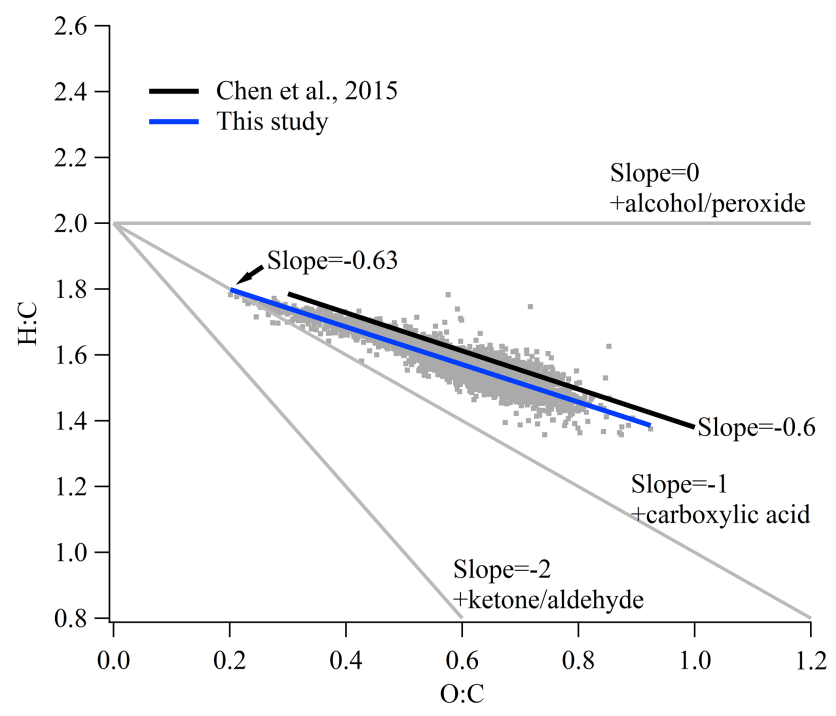

Figure 9. Van Krevelen diagram for the $\mathrm{O}: \mathrm{C}$ and $\mathrm{H}: \mathrm{C}$ ratios. The gray lines illustrate how functionalization reactions of organic species affect $\mathrm{H}: \mathrm{C}$ and $\mathrm{O}: \mathrm{C}$ from an arbitrary starting point (adopted from Heald et al., 2010).

linear fitting using HGF, not $\kappa_{\text {org }}$ ), they reported a linear relationship $\left(\mathrm{HGF}_{90} \%=(0.58 \pm 0.15) \cdot \mathrm{O}: \mathrm{C}+(0.85 \pm 0.08)\right)$ between $\mathrm{HGF}_{90} \%$ and $\mathrm{O}: \mathrm{C}$ for the laboratory-generated SOA particles. Both results displayed in Fig. 8 and Massoli's study showed a positive correlation between $\kappa_{\text {org }}$ and O:C. Such positive correlation was also reported by those studies based on CCNc measurements, for examples, Chang et al. (2010) and Mei et al. (2013). We note that the slopes of the linear fitting varied with different studies, indicating that there was not a simple parametrization to describe the relationship between organic hygroscopicity and its oxidation state though the various atmospheric environments.

In order to gain insight into the similarities of OA measured in Beijing and other environments, the average elemental composition, which is an approach to simply describe organic aerosol (OA) chemistry (Kroll et al., 2011) is analyzed here. The $\mathrm{O}: \mathrm{C}$ vs. $\mathrm{H}: \mathrm{C}$ ratios of OA (Van Krevelen diagram, V-K) can be used to characterize both the source profiles and the atmospheric evolution of OA (Heald et al., 2010; Ng et al., 2011). Figure 9 displays the V-K diagram for the $\mathrm{O}: \mathrm{C}$ and $\mathrm{H}: \mathrm{C}$ ratios during the entire sampling period in our study. The $\mathrm{O}: \mathrm{C}$ vs. $\mathrm{H}: \mathrm{C}$ ratios can be fitted by a line with a slope of -0.63 and an intercept of 1.95 by the reduced-major-axis (RMA) regression method. The V-K diagram for OA summarized by Chen et al. (2015) is also given in Fig. 9 in order to make comparisons between OA measured in Beijing and in other atmospheric environments. Chen et al. (2015) found that ambient organic aerosols line up in the V-K space along a line with a slope of -0.6 by synthesizing a large data set of surface field observations covering urban, rural, and remote environments. The trajectory 
of our work agrees well with this general trend, as shown in Fig. 9. It implies that the atmospheric aging of OA in Beijing has great similarities with the results measured in other locations.

The gray lines in Fig. 9 display a conceptual V-K diagram, illustrating how reactions involving the addition of functional groups fall along straight lines proposed by Heald et al. (2010). A slope of -1 is produced by the simultaneous addition of both functional groups, forming a hydroxycarbonyl or carboxylic acid. The horizontal line (slope $=0$ ) means that the replacement of a hydrogen with an alcohol group $(-\mathrm{OH})$ involves an increase in oxygen but no change in hydrogen (Heald et al., 2010). The slope for O : C vs. H: C ratios in our study falls into the space between lines with a slope of -1 and 0 . This indicates that the addition of both alcohol and carboxylic functions could lead to the enhancement of the $\mathrm{O}: \mathrm{C}$ ratio. However, these reactions could result in different particle hygroscopic behaviors. This could be one of the reasons to explain that O:C does not encompass changes in detailed chemical composition that are responsible for changes in hygroscopicity. Recently, Richards et al. (2013) undertook an extensive review of $\kappa$ values published in the literature and showed that $\kappa_{\text {org }}$ vs. O:C plot has a large degree of scatter. This indicates that other factors, such as phase state (Pajunoja et al., 2015) and molecular structures (Suda et al., 2014) of organic aerosols (OA) other than oxidation state may also play a role in the determination of the OA hygroscopicity.

\subsection{Case study: particle hygroscopicity during an NPF event}

As shown in Fig. 3a, the NPF events frequently took place during the sampling period. In order to understand the effects of NPF on particle hygroscopic behavior, this section will exemplify the evolution of particle hygroscopicity during an NPF event. As an example, Fig. 10 displays the time series of particle number size distribution, GF-PDFs and watersoluble fraction of 50 and $250 \mathrm{~nm}$ particles, and chemical composition of $\mathrm{PM}_{1}$ during an NPF event that occurred on 5 June 2014. Here, the particles $50 \mathrm{~nm}$ in diameter represented the newly formed particles, and particles $250 \mathrm{~nm}$ in diameter represented the pre-existing particles.

The NPF event started at around 10:30 LT and ended at 05:30 LT the next day. After the start of new particle formation, the number fraction of the hydrophilic mode for $50 \mathrm{~nm}$ particles increased from 0.5 to around 1, showing the conversion of externally to more internally mixed particles, as marked by the black dashed lines in Fig. 9b. Around 20:30 LT, the fraction of the hydrophilic mode particles dropped to 0.6, and the hydrophobic mode appeared again. This is attributed to the intensive traffic emissions at the time of rush hour, which can clearly be seen from the particle number size distribution. During nighttime, the growth factor of hydrophilic mode particles decreased. This can be

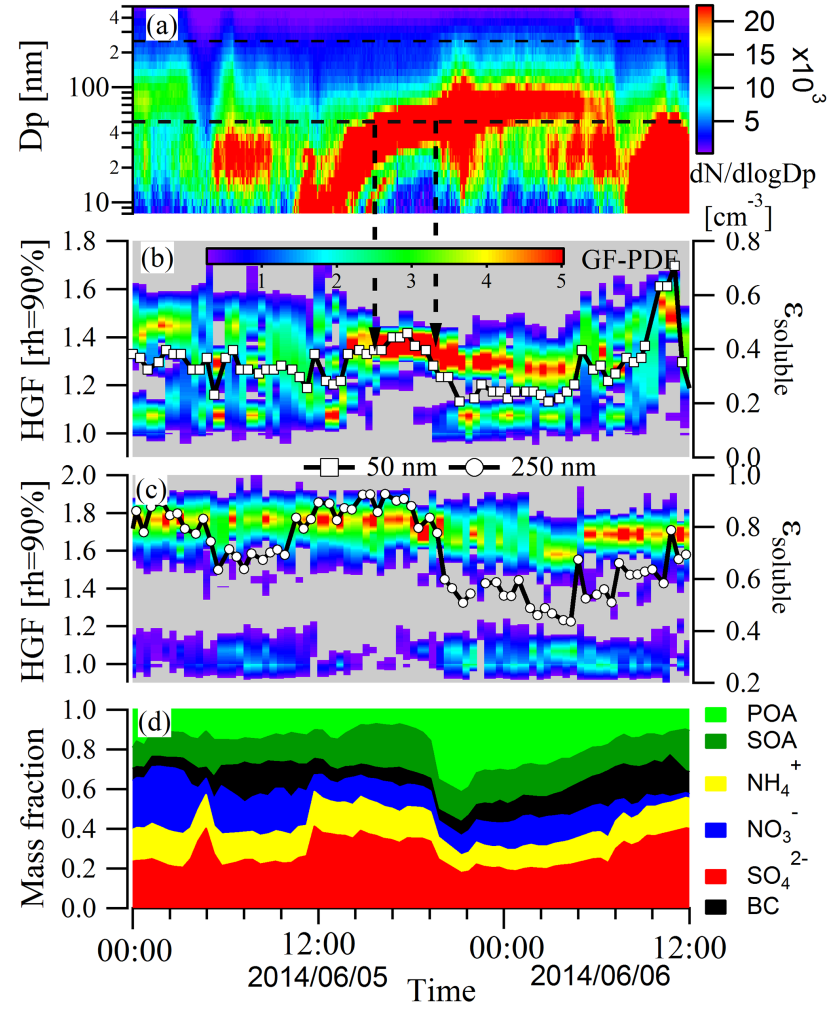

Figure 10. The variation in particle number size distribution (a), GF-PDF (b, c), water-soluble volume fraction (b, c), and chemical composition of $\mathrm{PM}_{1}$ (d) during an NPF event.

explained by sulfuric acid condensation playing a minor role in particle growth during nighttime. Simultaneously, ambient temperature decreased from 27 to $20^{\circ} \mathrm{C}$. Lower temperature facilitated the condensation of semi-volatile organic vapors onto the newly formed particles. The chemical composition of $\mathrm{PM}_{1}$ also (Fig. 9) showed that the inorganic species and SOA dominated before 20:30 LT, while the mass fraction of organic compounds, especially POA, increased significantly afterwards.

Clearly, an obvious enhancement in the water-soluble fraction of $50 \mathrm{~nm}$ particles took place after the NPF event started. A similar phenomenon was also observed by Shantz et al. (2012), who showed that the $36 \mathrm{~nm}$ particles became increasingly CCN active within 1-4 h after the nucleation during the NPF events. They hypothesized that the condensation of sulfate on these small particles enhanced their CCN activity. The water-soluble fraction accounted for $42 \%$ of $50 \mathrm{~nm}$ newly formed particles. The water-soluble fraction was most likely ammonium sulfate formed from a neutralization reaction between ammonia and sulfuric acid. In contrast, the newly formed particles consisted of a minor fraction of water-soluble fraction (16\%) in Hyytiälä, Finland (Ehn et al., 2007). Other observations in the clean atmospheric environments (relative to Beijing), such as a forested site in Colorado (Levin et al., 2012), Mace Head, Ireland (Väkevä 
et al., 2002), and Melpitz, Germany (Wu et al., 2015), also showed that low water-soluble compounds, most likely secondary organic species, mainly contributed to new particle growth. Differently, in the urban area of Atlanta (Sakurai et al., 2005), the water-soluble fraction dominated in the newly formed particles, which was similar to our observation in this study.

As shown in Fig. 9c, the fraction of the hydrophilic mode of $250 \mathrm{~nm}$ particles increased significantly and approached 1 after the NPF event started. This can be explained as such: during the particle formation, a large amount of condensable vapors, such as sulfuric acid and secondary organic species, were produced because of the strongly active photochemistry. These condensable vapors can condense onto the preexisting particles and result in the transformation of external mixtures to internal mixtures. Such a transformation may alter the atmospheric behaviors of pre-existing particles, such as optical properties and cloud condensation nuclei activation during the new particle formation events.

\section{Conclusions}

Particle number size distribution, particle hygroscopicity, and size-resolved chemical composition were measured concurrently during summertime 2014 in Beijing, China. The particle hygroscopicity showed a pronounced size dependency. It increased with increasing particle size. During the measurement period, the mean $\kappa \mathrm{s}$ of $50,100,150$, 200 , and $250 \mathrm{~nm}$ particles are $0.16 \pm 0.07,0.19 \pm 0.06$, $0.22 \pm 0.06,0.26 \pm 0.07$, and $0.28 \pm 0.10$, respectively. The size-dependency behavior of particle hygroscopicity was similar to that of inorganic compounds in $\mathrm{PM}_{1}$. The hydrophilic mode (HGF $>1.2$ ) was more prominent, no matter what particle size was considered. With increasing particle size, the dominance of hydrophilic mode became more pronounced. When $\mathrm{PM}_{2.5}$ mass concentration was below $50 \mu \mathrm{g} \mathrm{m}^{-3}$, no dependency between $\mathrm{PM}_{2.5}$ mass concentration and the number fraction of hydrophilic mode was found. Above $50 \mathrm{\mu g} \mathrm{m}^{-3}$, the number fraction of hydrophilic mode for 150,250 , and $350 \mathrm{~nm}$ particles increased and rose towards 1 with the increasing $\mathrm{PM}_{2.5}$ mass concentration. This means that aged particles dominated the particle mass concentration, especially during severe particulate pollution events in Beijing. Based on the size-resolved AMS data, the particle hygroscopic growth can be well predicted using the ZSR method. The organic hygroscopicity parameter showed a positive correlation with the $\mathrm{O}: \mathrm{C}$ ratio.

Frequent new particle formation events took place during the measuring period. The hygroscopic growth factor or $\kappa$ of newly formed particles was greater than the hygroscopic growth factor of particles with the same sizes during nonNPF periods. During new particle formation, fast transformations of external mixtures to internal mixtures for existing particles (for example, $250 \mathrm{~nm}$ particles) have been observed.
This was a strong indication that secondary aerosol material such as organics and sulfates was produced due to the strongly active photochemistry during NPF events, and subsequently condensed onto the particles. Such a transformation may modify the atmospheric behaviors of pre-existing particles, such as optical properties and cloud condensation nuclei activation.

Acknowledgements. This work is supported by the following projects: National Natural Science Foundation of China (41475127, 91544214), National Basic Research Program of China (2013CB228503), The Strategic Priority Research Program of the China Academy of Sciences (XDB05010500), Special Fund of State Key Joint Laboratory of Environment Simulation and Pollution Control (14L02ESPC), the nonprofit research projects of the Ministry of Environmental Protection, the People's Republic of China (201409010), and the Collaborative Innovation Center for Regional Environmental Quality. The authors would like to greatly thank Douglas R. Worsnop and Qi Chen for useful discussions about the AMS data processing.

Edited by: R. Sullivan

\section{References}

Achtert, P., Birmili, W., Nowak, A., Wehner, B., Wiedensohler, A., Takegawa, N., Kondo, Y., Miyazaki, Y., Hu, M., and Zhu, T.: Hygroscopic growth of tropospheric particle number size distributions over the North China Plain, J. Geophys. Res.-Atmos., 114, D00G07, doi:10.1029/2008JD010921, 2009.

Aiken, A. C., DeCarlo, P. F., Kroll, J. H., Worsnop, D. R., Huffman, J. A., Docherty, K. S., Ulbrich, I. M., Mohr, C., Kimmel, J. R., Sueper, D., Sun, Y., Zhang, Q., Trimborn, A., Northway, M., Ziemann, P. J., Canagaratna, M. R., Onasch, T. B., Alfarra, M. R., Prevot, A. S. H., Dommen, J., Duplissy, J., Metzger, A., Baltensperger, U., and Jimenez, J. L.: O/C and OM/OC Ratios of Primary, Secondary, and Ambient Organic Aerosols with HighResolution Time-of-Flight Aerosol Mass Spectrometry, Environ. Sci. Technol., 42, 4478-4485, doi:10.1021/es703009q, 2008.

Alfarra, M. R., Paulsen, D., Gysel, M., Garforth, A. A., Dommen, J., Prévôt, A. S. H., Worsnop, D. R., Baltensperger, U., and Coe, H.: A mass spectrometric study of secondary organic aerosols formed from the photooxidation of anthropogenic and biogenic precursors in a reaction chamber, Atmos. Chem. Phys., 6, 52795293, doi:10.5194/acp-6-5279-2006, 2006.

Arnott, P., Moosmüller, H., Fred Rogers, C., Jin, T., and Bruch, R.: Photoacoustic spectrometer for measuring light absorption by aerosol: instrument description, Atmos. Environ., 33, 28452852, doi:10.1016/S1352-2310(98)00361-6, 1999.

Bhattu, D. and Tripathi, S. N.: CCN closure study: Effects of aerosol chemical composition and mixing state, J. Geophys. Res.-Atmos., 120, 766-783, doi:10.1002/2014JD021978, 2015.

Canagaratna, M. R., Jayne, J. T., Jimenez, J. L., Allan, J. D., Alfarra, M. R., Zhang, Q., Onasch, T. B., Drewnick, F., Coe, H., Middlebrook, A., Delia, A., Williams, L. R., Trimborn, A. M., Northway, M. J., DeCarlo, P. F., Kolb, C. E., Davidovits, P., and Worsnop, D. R.: Chemical and microphysical characterization 
of ambient aerosols with the aerodyne aerosol mass spectrometer, Mass. Spectrom. Rev., 26, 185-222, doi:10.1002/mas.20115, 2007.

Canagaratna, M. R., Jimenez, J. L., Kroll, J. H., Chen, Q., Kessler, S. H., Massoli, P., Hildebrandt Ruiz, L., Fortner, E., Williams, L. R., Wilson, K. R., Surratt, J. D., Donahue, N. M., Jayne, J. T., and Worsnop, D. R.: Elemental ratio measurements of organic compounds using aerosol mass spectrometry: characterization, improved calibration, and implications, Atmos. Chem. Phys., 15, 253-272, doi:10.5194/acp-15-253-2015, 2015.

Cerully, K. M., Raatikainen, T., Lance, S., Tkacik, D., Tiitta, P., Petäjä, T., Ehn, M., Kulmala, M., Worsnop, D. R., Laaksonen, A., Smith, J. N., and Nenes, A.: Aerosol hygroscopicity and $\mathrm{CCN}$ activation kinetics in a boreal forest environment during the 2007 EUCAARI campaign, Atmos. Chem. Phys., 11, 1236912386, doi:10.5194/acp-11-12369-2011, 2011.

Chang, R. Y. W., Slowik, J. G., Shantz, N. C., Vlasenko, A., Liggio, J., Sjostedt, S. J., Leaitch, W. R., and Abbatt, J. P. D.: The hygroscopicity parameter $(\kappa)$ of ambient organic aerosol at a field site subject to biogenic and anthropogenic influences: relationship to degree of aerosol oxidation, Atmos. Chem. Phys., 10, 5047-5064, doi:10.5194/acp-10-5047-2010, 2010.

Chen, Q., Li, Y. L., McKinney, K. A., Kuwata, M., and Martin, S. T.: Particle mass yield from $\beta$-caryophyllene ozonolysis, Atmos. Chem. Phys., 12, 3165-3179, doi:10.5194/acp-12-31652012, 2012.

Chen, Q., Heald, C. L., Jimenez, J. L., Canagaratna, M. R., Zhang, Q., He, L.-Y., Huang, X.-F., Campuzano-Jost, P., Palm, B. B., Poulain, L., Kuwata, M., Martin, S. T., Abbatt, J. P. D., Lee, A. K. Y., and Liggio, J.: Elemental composition of organic aerosol: The gap between ambient and laboratory measurements, Geophys. Res. Lett., 42, 4182-4189, doi:10.1002/2015GL063693, 2015.

Cheng, Y. F., Wiedensohler, A., Eichler, H., Heintzenberg, J., Tesche, M., Ansmann, A., Wendisch, M., Su, H., Althausen, D., Herrmann, H., Gnauk, T., Brüggemann, E., Hu, M., and Zhang, Y. H.: Relative humidity dependence of aerosol optical properties and direct radiative forcing in the surface boundary layer at Xinken in Pearl River Delta of China: An observation based numerical study, Atmos. Environ., 42, 6373-6397, doi:10.1016/j.atmosenv.2008.04.009, 2008.

Clarke, A. D., Owens, S. R., and Zhou, J.: An ultrafine sea-salt flux from breaking waves: Implications for cloud condensation nuclei in the remote marine atmosphere, J. Geophys. Res.-Atmos., 111, D06202, doi:10.1029/2005JD006565, 2006.

DeCarlo, P. F., Kimmel, J. R., Trimborn, A., Northway, M. J., Jayne, J. T., Aiken, A. C., Gonin, M., Fuhrer, K., Horvath, T., Docherty, K. S., Worsnop, D. R., and Jimenez, J. L.: Field-deployable, high-resolution, time-of-flight aerosol mass spectrometer, Anal. Chem., 78, 8281-8289, doi:10.1021/ac061249n, 2006.

Dinar, E., Mentel, T. F., and Rudich, Y.: The density of humic acids and humic like substances (HULIS) from fresh and aged wood burning and pollution aerosol particles, Atmos. Chem. Phys., 6, 5213-5224, doi:10.5194/acp-6-5213-2006, 2006.

Draxler, R. R. and Hess, G. D.: An overview of the HYSPLIT_4 modelling system for trajectories dispersion and deposition, Aust. Meteorol. Mag., 47, 295-308, 1998.

Duplissy, J., DeCarlo, P. F., Dommen, J., Alfarra, M. R., Metzger, A., Barmpadimos, I., Prevot, A. S. H., Weingartner, E., Tritscher,
T., Gysel, M., Aiken, A. C., Jimenez, J. L., Canagaratna, M. R., Worsnop, D. R., Collins, D. R., Tomlinson, J., and Baltensperger, U.: Relating hygroscopicity and composition of organic aerosol particulate matter, Atmos. Chem. Phys., 11, 11551165, doi:10.5194/acp-11-1155-2011, 2011.

Ehn, M., Petäjä, T., Aufmhoff, H., Aalto, P., Hämeri, K., Arnold, F., Laaksonen, A., and Kulmala, M.: Hygroscopic properties of ultrafine aerosol particles in the boreal forest: diurnal variation, solubility and the influence of sulfuric acid, Atmos. Chem. Phys., 7, 211-222, doi:10.5194/acp-7-211-2007, 2007.

Fors, E. O., Swietlicki, E., Svenningsson, B., Kristensson, A., Frank, G. P., and Sporre, M.: Hygroscopic properties of the ambient aerosol in southern Sweden - a two year study, Atmos. Chem. Phys., 11, 8343-8361, doi:10.5194/acp-11-8343-2011, 2011.

Gunthe, S. S., King, S. M., Rose, D., Chen, Q., Roldin, P., Farmer, D. K., Jimenez, J. L., Artaxo, P., Andreae, M. O., Martin, S. T., and Pöschl, U.: Cloud condensation nuclei in pristine tropical rainforest air of Amazonia: size-resolved measurements and modeling of atmospheric aerosol composition and $\mathrm{CCN}$ activity, Atmos. Chem. Phys., 9, 7551-7575, doi:10.5194/acp-9-75512009, 2009.

Guo, S., Hu, M., Zamora, M. L., Peng, J., Shang, D., Zheng, J., Du, Z., Wu, Z., Shao, M., Zeng, L., Molina, M. J., and Zhang, R.: Elucidating severe urban haze formation in China, P. Natl. Acad. Sci., 111, 17373-17378, doi:10.1073/pnas.1419604111, 2014.

Gysel, M., Crosier, J., Topping, D. O., Whitehead, J. D., Bower, K. N., Cubison, M. J., Williams, P. I., Flynn, M. J., McFiggans, G. B., and Coe, H.: Closure study between chemical composition and hygroscopic growth of aerosol particles during TORCH2, Atmos. Chem. Phys., 7, 6131-6144, doi:10.5194/acp-7-61312007, 2007.

Gysel, M., McFiggans, G. B., and Coe, H.: Inversion of tandem differential mobility analyser (TDMA) measurements, J. Aerosol Sci., 40, 134-151, doi:10.1016/j.jaerosci.2008.07.013, 2009.

Hallquist, M., Wenger, J. C., Baltensperger, U., Rudich, Y., Simpson, D., Claeys, M., Dommen, J., Donahue, N. M., George, C., Goldstein, A. H., Hamilton, J. F., Herrmann, H., Hoffmann, T., Iinuma, Y., Jang, M., Jenkin, M. E., Jimenez, J. L., Kiendler-Scharr, A., Maenhaut, W., McFiggans, G., Mentel, Th. F., Monod, A., Prévôt, A. S. H., Seinfeld, J. H., Surratt, J. D., Szmigielski, R., and Wildt, J.: The formation, properties and impact of secondary organic aerosol: current and emerging issues, Atmos. Chem. Phys., 9, 5155-5236, doi:10.5194/acp-9-51552009, 2009.

Haywood, J. and Boucher, O.: Estimates of the direct and indirect radiative forcing due to tropospheric aerosols: A review, Rev. Geophys., 38, 513-543, doi:10.1029/1999RG000078, 2000.

Heald, C. L., Kroll, J. H., Jimenez, J. L., Docherty, K. S., DeCarlo, P. F., Aiken, A. C., Chen, Q., Martin, S. T., Farmer, D. K., and Artaxo, P.: A simplified description of the evolution of organic aerosol composition in the atmosphere, Geophysical Research Letters, 37, L08803, doi:10.1029/2010GL042737, 2010.

Huang, R.-J., Zhang, Y., Bozzetti, C., Ho, K.-F., Cao, J.-J., Han, Y., Daellenbach, K. R., Slowik, J. G., Platt, S. M., Canonaco, F., Zotter, P., Wolf, R., Pieber, S. M., Bruns, E. A., Crippa, M., Ciarelli, G., Piazzalunga, A., Schwikowski, M., Abbaszade, G., SchnelleKreis, J., Zimmermann, R., An, Z., Szidat, S., Baltensperger, U., Haddad, I. E., and Prevot, A. S. H.: High secondary aerosol con- 
tribution to particulate pollution during haze events in China, Nature, 514, 218-222, doi:10.1038/nature13774, 2014.

Huang, X. F., Yu, J. Z., He, L. Y., and Hu, M.: Size distribution characteristics of elemental carbon emitted from Chinese vehicles: Results of a tunnel study and atmospheric implications, Enviro. Sci. Technol., 40, 5355-5360, doi:10.1021/es0607281, 2006.

Jimenez, J. L., Canagaratna, M. R., Donahue, N. M., Prevot, A. S. H., Zhang, Q., Kroll, J. H., DeCarlo, P. F., Allan, J. D., Coe, H., Ng, N. L., Aiken, A. C., Docherty, K. S., Ulbrich, I. M., Grieshop, A. P., Robinson, A. L., Duplissy, J., Smith, J. D., Wilson, K. R., Lanz, V. A., Hueglin, C., Sun, Y. L., Tian, J., Laaksonen, A., Raatikainen, T., Rautiainen, J., Vaattovaara, P., Ehn, M., Kulmala, M., Tomlinson, J. M., Collins, D. R., Cubison, M. J., E, Dunlea, J., Huffman, J. A., Onasch, T. B., Alfarra, M. R., Williams, P. I., Bower, K., Kondo, Y., Schneider, J., Drewnick, F., Borrmann, S., Weimer, S., Demerjian, K., Salcedo, D., Cottrell, L., Griffin, R., Takami, A., Miyoshi, T., Hatakeyama, S., Shimono, A., Sun, J. Y., Zhang, Y. M., Dzepina, K., Kimmel, J. R., Sueper, D., Jayne, J. T., Herndon, S. C., Trimborn, A. M., Williams, L. R., Wood, E. C., Middlebrook, A. M., Kolb, C. E., Baltensperger, U., and Worsnop, D. R.: Evolution of organic aerosols in the atmosphere, Science, 326, 1525-1529, doi:10.1126/science.1180353, 2009.

Jurányi, Z., Tritscher, T., Gysel, M., Laborde, M., Gomes, L., Roberts, G., Baltensperger, U., and Weingartner, E.: Hygroscopic mixing state of urban aerosol derived from sizeresolved cloud condensation nuclei measurements during the MEGAPOLI campaign in Paris, Atmos. Chem. Phys., 13, 64316446, doi:10.5194/acp-13-6431-2013, 2013.

Kanakidou, M., Seinfeld, J. H., Pandis, S. N., Barnes, I., Dentener, F. J., Facchini, M. C., Van Dingenen, R., Ervens, B., Nenes, A., Nielsen, C. J., Swietlicki, E., Putaud, J. P., Balkanski, Y., Fuzzi, S., Horth, J., Moortgat, G. K., Winterhalter, R., Myhre, C. E. L., Tsigaridis, K., Vignati, E., Stephanou, E. G., and Wilson, J.: Organic aerosol and global climate modelling: a review, Atmos. Chem. Phys., 5, 1053-1123, doi:10.5194/acp-5-1053-2005, 2005.

Kiselev, A., Wennrich, C., Stratmann, F., Wex, H., Henning, S., Mentel, T. F., Kiendler-Scharr, A., Schneider, J., Walter, S., and Lieberwirth, I.: Morphological characterization of soot aerosol particles during LACIS Experiment in November (LExNo), J. Geophys. Res.-Atmos., 115, D11204, doi:10.1029/2009jd012635, 2010.

Koehler, K. A., Kreidenweis, S. M., DeMott, P. J., Petters, M. D., Prenni, A. J., and Carrico, C. M.: Hygroscopicity and cloud droplet activation of mineral dust aerosol, Geophysical Research Letters, 36, L08805, doi:10.1029/2009GL037348, 2009.

Kondo, Y., Sahu, L., Moteki, N., Khan, F., Takegawa, N., Liu, X., Koike, M., and Miyakawa, T.: Consistency and Traceability of Black Carbon Measurements Made by Laser-Induced Incandescence, Thermal-Optical Transmittance, and Filter-Based Photo-Absorption Techniques, Aerosol Sci. Tech. 45, 295-312, doi:10.1080/02786826.2010.533215, 2011.

Kostenidou, E., Pathak, R. K., and Pandis, S. N.: An Algorithm for the Calculation of Secondary Organic Aerosol Density Combining AMS and SMPS Data, Aerosol Sci. Tech., 41, 1002-1010, doi:10.1080/02786820701666270, 2007.

Kreidenweis, S. M. and Asa-Awuku, A.: 5.13 - Aerosol Hygroscopicity: Particle Water Content and Its Role in Atmospheric
Processes, in: Treatise on Geochemistry, 2nd Edn., edited by: Turekian, H. D. H. K., Elsevier, Oxford, 331-361, 2014.

Kroll, J. H., Donahue, N. M., Jimenez, J. L., Kessler, S. H., Canagaratna, M. R., Wilson, K. R., Altieri, K. E., Mazzoleni, L. R., Wozniak, A. S., Bluhm, H., Mysak, E. R., Smith, J. D., Kolb, C. E., and Worsnop, D. R.: Carbon oxidation state as a metric for describing the chemistry of atmospheric organic aerosol, Nat. Chem., 3, 133-139, 2011.

Lambe, A. T., Onasch, T. B., Massoli, P., Croasdale, D. R., Wright, J. P., Ahern, A. T., Williams, L. R., Worsnop, D. R., Brune, W. H., and Davidovits, P.: Laboratory studies of the chemical composition and cloud condensation nuclei $(\mathrm{CCN})$ activity of secondary organic aerosol (SOA) and oxidized primary organic aerosol (OPOA), Atmos. Chem. Phys., 11, 8913-8928, doi:10.5194/acp-11-8913-2011, 2011.

Lanz, V. A., Alfarra, M. R., Baltensperger, U., Buchmann, B., Hueglin, C., and Prévôt, A. S. H.: Source apportionment of submicron organic aerosols at an urban site by factor analytical modelling of aerosol mass spectra, Atmos. Chem. Phys., 7, 15031522, doi:10.5194/acp-7-1503-2007, 2007.

Levin, E. J. T., Prenni, A. J., Petters, M. D., Kreidenweis, S. M., Sullivan, R. C., Atwood, S. A., Ortega, J., DeMott, P. J., and Smith, J. N.: An annual cycle of size-resolved aerosol hygroscopicity at a forested site in Colorado, J. Geophys. Res., 117, D06201, doi:10.1029/2011jd016854, 2012.

Levin, E. J. T., Prenni, A. J., Palm, B. B., Day, D. A., CampuzanoJost, P., Winkler, P. M., Kreidenweis, S. M., DeMott, P. J., Jimenez, J. L., and Smith, J. N.: Size-resolved aerosol composition and its link to hygroscopicity at a forested site in Colorado, Atmos. Chem. Phys., 14, 2657-2667, doi:10.5194/acp-14-26572014, 2014.

Li, L., Wang, Y., Zhang, Q., Li, J., Yang, X., and Jin, J.: Wheat straw burning and its associated impacts on Beijing air quality, Sci. China Ser. D, 51, 403-414, 2008.

Liu, P. F., Zhao, C. S., Göbel, T., Hallbauer, E., Nowak, A., Ran, L., Xu, W. Y., Deng, Z. Z., Ma, N., Mildenberger, K., Henning, S., Stratmann, F., and Wiedensohler, A.: Hygroscopic properties of aerosol particles at high relative humidity and their diurnal variations in the North China Plain, Atmos. Chem. Phys., 11, 3479-3494, doi:10.5194/acp-11-3479-2011, 2011.

Lopez-Yglesias, X. F., Yeung, M. C., Dey, S. E., Brechtel, F. J., and Chan, C. K.: Performance Evaluation of the Brechtel Mfg. Humidified Tandem Differential Mobility Analyzer (BMI HTDMA) for Studying Hygroscopic Properties of Aerosol Particles, Aerosol Sci. Tech., 48, 969-980, doi:10.1080/02786826.2014.952366, 2014.

Malm, W. C. and Kreidenweis, S. M.: The effects of models of aerosol hygroscopicity on the apportionment of extinction, Atmos. Environ., 31, 1965-1976, doi:10.1016/s13522310(96)00355-x, 1997.

Massling, A., Wiedensohler, A., Busch, B., Neusüß, C., Quinn, P., Bates, T., and Covert, D.: Hygroscopic properties of different aerosol types over the Atlantic and Indian Oceans, Atmos. Chem. Phys., 3, 1377-1397, doi:10.5194/acp-3-1377-2003, 2003.

Massling, A., Stock, M., Wehner, B., Wu, Z. J., Hu, M., Brüggemann, E., Gnauk, T., Herrmann, H., and Wiedensohler, A.: Size segregated water uptake of the urban submicrometer aerosol in Beijing, Atmos. Environ., 43, 1578-1589, doi:10.1016/j.atmosenv.2008.06.003, 2009. 
Massling, A., Niedermeier, N., Hennig, T., Fors, E. O., Swietlicki, E., Ehn, M., Hämeri, K., Villani, P., Laj, P., Good, N., McFiggans, G., and Wiedensohler, A.: Results and recommendations from an intercomparison of six Hygroscopicity-TDMA systems, Atmos. Meas. Tech., 4, 485-497, doi:10.5194/amt-4-485-2011, 2011

Massoli, P., Lambe, A. T., Ahern, A. T., Williams, L. R., Ehn, M., Mikkilä, J., Canagaratna, M. R., Brune, W. H., Onasch, T. B., Jayne, J. T., Petäjä, T., Kulmala, M., Laaksonen, A., Kolb, C. E., Davidovits, P., and Worsnop, D. R.: Relationship between aerosol oxidation level and hygroscopic properties of laboratory generated secondary organic aerosol (SOA) particles, Geophys. Res. Lett., 37, L24801, doi:10.1029/2010GL045258, 2010.

McFiggans, G., Artaxo, P., Baltensperger, U., Coe, H., Facchini, M. C., Feingold, G., Fuzzi, S., Gysel, M., Laaksonen, A., Lohmann, U., Mentel, T. F., Murphy, D. M., O’Dowd, C. D., Snider, J. R., and Weingartner, E.: The effect of physical and chemical aerosol properties on warm cloud droplet activation, Atmos. Chem. Phys., 6, 2593-2649, doi:10.5194/acp-6-2593-2006, 2006.

McMurry, P. H., Wang, X., Park, K., and Ehara, K.: The Relationship between Mass and Mobility for Atmospheric Particles: A New Technique for Measuring Particle Density, Aerosol Sci. Tech., 36, 227-238, doi:10.1080/027868202753504083, 2002.

Medina, J., Nenes, A., Sotiropoulou, R.-E. P., Cottrell, L. D., Ziemba, L. D., Beckman, P. J., and Griffin, R. J.: Cloud condensation nuclei closure during the International Consortium for Atmospheric Research on Transport and Transformation 2004 campaign: Effects of size-resolved composition, J. Geophys. Res., 112, D10S31, doi:10.1029/2006jd007588, 2007.

Mei, F., Hayes, P. L., Ortega, A., Taylor, J. W., Allan, J. D., Gilman, J., Kuster, W., de Gouw, J., Jimenez, J. L., and Wang, J.: Droplet activation properties of organic aerosols observed at an urban site during CalNex-LA, J. Geophys. Res.-Atmos., 118, 2903-2917, doi:10.1002/jgrd.50285, 2013.

Meier, J., Wehner, B., Massling, A., Birmili, W., Nowak, A., Gnauk, T., Brüggemann, E., Herrmann, H., Min, H., and Wiedensohler, A.: Hygroscopic growth of urban aerosol particles in Beijing (China) during wintertime: a comparison of three experimental methods, Atmos. Chem. Phys., 9, 6865-6880, doi:10.5194/acp9-6865-2009, 2009.

Moore, R. H., Cerully, K., Bahreini, R., Brock, C. A., Middlebrook, A. M., and Nenes, A.: Hygroscopicity and composition of California CCN during summer 2010, J. Geophys. Res.-Atmos., 117, D00V12, doi:10.1029/2011JD017352, 2012a.

Moore, R. H., Raatikainen, T., Langridge, J. M., Bahreini, R., Brock, C. A., Holloway, J. S., Lack, D. A., Middlebrook, A. M., Perring, A. E., Schwarz, J. P., Spackman, J. R., and Nenes, A.: CCN Spectra, Hygroscopicity, and Droplet Activation Kinetics of Secondary Organic Aerosol Resulting from the 2010 Deepwater Horizon Oil Spill, Environ. Sci. Technol., 46, 3093-3100, doi:10.1021/es203362w, 2012b.

Ng, N. L., Canagaratna, M. R., Jimenez, J. L., Chhabra, P. S., Seinfeld, J. H., and Worsnop, D. R.: Changes in organic aerosol composition with aging inferred from aerosol mass spectra, Atmos. Chem. Phys., 11, 6465-6474, doi:10.5194/acp-11-64652011, 2011.

Pajunoja, A., Lambe, A. T., Hakala, J., Rastak, N., Cummings, M. J., Brogan, J. F., Hao, L., Paramonov, M., Hong, J., Prisle, N. L., Malila, J., Romakkaniemi, S., Lehtinen, K. E. J., Laak- sonen, A., Kulmala, M., Massoli, P., Onasch, T. B., Donahue, N. M., Riipinen, I., Davidovits, P., Worsnop, D. R., Petäjä, T., and Virtanen, A.: Adsorptive uptake of water by semisolid secondary organic aerosols, Geophys. Res. Lett., 42, 3063-3068, doi:10.1002/2015GL063142, 2015.

Paramonov, M., Aalto, P. P., Asmi, A., Prisle, N., Kerminen, V. M., Kulmala, M., and Petäjä, T.: The analysis of size-segregated cloud condensation nuclei counter (CCNC) data and its implications for cloud droplet activation, Atmos. Chem. Phys., 13, 10285-10301, doi:10.5194/acp-13-10285-2013, 2013.

Park, K., Kittelson, D. B., Zachariah, M. R., and McMurry, P. H.: Measurement of inherent material density of nanoparticle agglomerates, J. Nanopart. Res., 6, 267-272, 2004.

Petters, M. D. and Kreidenweis, S. M.: A single parameter representation of hygroscopic growth and cloud condensation nucleus activity, Atmos. Chem. Phys., 7, 1961-1971, doi:10.5194/acp-71961-2007, 2007.

Pöschl, U.: Atmospheric aerosols: Composition, transformation, climate and health effects, Angew. Chem. - Int. Edn., 44, 7520 7541, 2005.

Potukuchi, S. and Wexler, A. S.: Identifying solid-aqueous phase transitions in atmospheric aerosols - I. Neutral-acidity solutions, Atmos. Environ., 29, 1663-1676, doi:10.1016/13522310(95)00074-9, 1995.

Rickards, A. M. J., Miles, R. E. H., Davies, J. F., Marshall, F. H., and Reid, J. P.: Measurements of the Sensitivity of Aerosol Hygroscopicity and the $\kappa$ Parameter to the O/C Ratio, J. Phys. Chem. A, 117, 14120-14131, doi:10.1021/jp407991n, 2013.

Sakurai, H., Fink, M. A., McMurry, P. H., Mauldin, L., Moore, K. F., Smith, J. N., and Eisele, F. L.: Hygroscopicity and volatility of 4-10 nm particles during summertime atmospheric nucleation events in urban Atlanta, J. Geophys. Res.-Atmos., 110, D22S04, doi:10.1029/2005JD005918, 2005.

Shantz, N. C., Pierce, J. R., Chang, R. Y. W., Vlasenko, A., Riipinen, I., Sjostedt, S., Slowik, J. G., Wiebe, A., Liggio, J., Abbatt, J. P. D., and Leaitch, W. R.: Cloud condensation nuclei droplet growth kinetics of ultrafine particles during anthropogenic nucleation events, Atmos. Environ., 47, 389-398, doi:10.1016/j.atmosenv.2011.10.049, 2012.

Shao, L. Y., LI, W. J., Yang, S. S., Shi, Z. B., and Lu, S. L.: Mineralogical characteristics of airborne particles collected in Beijing during a severe Asian dust storm period in spring 2002, Sci. China Earth Sci., 50, 953-959, doi:10.1007/s11430-007-0035-7, 2007.

Sihto, S. L., Mikkilä, J., Vanhanen, J., Ehn, M., Liao, L., Lehtipalo, K., Aalto, P. P., Duplissy, J., Petäjä, T., Kerminen, V. M., Boy, M., and Kulmala, M.: Seasonal variation of CCN concentrations and aerosol activation properties in boreal forest, Atmos. Chem. Phys., 11, 13269-13285, doi:10.5194/acp-11-13269-2011, 2011.

Sloane, C. S. and Wolff, G. T.: Prediction of ambient light scattering using a physical model responsive to relative humidity: Validation with measurements from detroit, Atmos. Environ., 19, 669680, doi:10.1016/0004-6981(85)90046-0, 1985.

Song, Y., Tang, X., Xie, S., Zhang, Y., Wei, Y., Zhang, M., Zeng, L., and Lu, S.: Source apportionment of $\mathrm{PM}_{2.5}$ in Beijing in 2004, J. Hazard. Mater., 146, 124-130, doi:10.1016/j.jhazmat.2006.11.058, 2007. 
Stokes, R. H. and Robinson, R. A.: Interactions in Aqueous Nonelectrolyte Solutions. I. Solute-Solvent Equilibria, J. Phys. Chem., 70, 2126-2130, 1966.

Suda, S. R., Petters, M. D., Yeh, G. K., Strollo, C., Matsunaga, A., Faulhaber, A., Ziemann, P. J., Prenni, A. J., Carrico, C. M., Sullivan, R. C., and Kreidenweis, S. M.: Influence of Functional Groups on Organic Aerosol Cloud Condensation Nucleus Activity, Environ. Sci. Technol., 48, 10182-10190, doi:10.1021/es502147y, 2014.

Sun, T. L., He, L. Y., Zeng, L. W., and Huang, X. F.: Black carbon measurement during Beijing Paralympic Games, China Environ. Sci., 32, 2123-2127, 2012a.

Sun, Y. L., Zhang, Q., Schwab, J. J., Yang, T., Ng, N. L., and Demerjian, K. L.: Factor analysis of combined organic and inorganic aerosol mass spectra from high resolution aerosol mass spectrometer measurements, Atmos. Chem. Phys., 12, 8537-8551, doi:10.5194/acp-12-8537-2012, 2012 b.

Swietlicki, E., Zhou, J., Berg, O. H., Martinsson, B. G., Frank, G., Cederfelt, S.-I., Dusek, U., Berner, A., Birmili, W., Wiedensohler, A., Yuskiewicz, B., and Bower, K. N.: A closure study of sub-micrometer aerosol particle hygroscopic behaviour, Atmos. Res., 50, 205-240, doi:10.1016/s0169-8095(98)00105-7, 1999.

Swietlicki, E., Hansson, H. C., HÄMeri, K., Svenningsson, B., Massling, A., McFiggans, G., McMurry, P. H., PetÄJÄ, T., Tunved, P., Gysel, M., Topping, D., Weingartner, E., Baltensperger, U., Rissler, J., Wiedensohler, A., and Kulmala, M.: Hygroscopic properties of submicrometer atmospheric aerosol particles measured with H-TDMA instruments in various environments - a review, Tellus B, 60, 432-469, doi:10.1111/j.16000889.2008.00350.x, 2008.

Tang, I. N. and Munkelwitz, H. R.: Water activities, densities, and refractive indices of aqueous sulfates and sodium nitrate droplets of atmospheric importance, J. Geophys. Res., 99, 18801-18808, doi:10.1029/94jd01345, 1994.

Ulbrich, I. M., Canagaratna, M. R., Zhang, Q., Worsnop, D. R., and Jimenez, J. L.: Interpretation of organic components from Positive Matrix Factorization of aerosol mass spectrometric data, Atmos. Chem. Phys., 9, 2891-2918, doi:10.5194/acp-9-2891-2009, 2009.

Väkevä, M., Hämeri, K., and Aalto, P. P.: Hygroscopic properties of nucleation mode and Aitken mode particles during nucleation bursts and in background air on the west coast of Ireland, J. Geophys. Res.-Atmos., 107, PAR 9-1-PAR 9-11, doi:10.1029/2000JD000176, 2002.

Varutbangkul, V., Brechtel, F. J., Bahreini, R., Ng, N. L., Keywood, M. D., Kroll, J. H., Flagan, R. C., Seinfeld, J. H., Lee, A., and Goldstein, A. H.: Hygroscopicity of secondary organic aerosols formed by oxidation of cycloalkenes, monoterpenes, sesquiterpenes, and related compounds, Atmos. Chem. Phys., 6, 23672388, doi:10.5194/acp-6-2367-2006, 2006.

Virkkula, A., Van Dingenen, R., Raes, F., and Hjorth, J.: Hygroscopic properties of aerosol formed by oxidation of limonene, $\alpha$-pinene, and $\beta$-pinene, J. Geophys. Res., 104, 3569-3579, doi:10.1029/1998jd100017, 1999.

Wehner, B., Birmili, W., Ditas, F., Wu, Z., Hu, M., Liu, X., Mao, J., Sugimoto, N., and Wiedensohler, A.: Relationships between submicrometer particulate air pollution and air mass history in Beijing, China, 2004-2006, Atmos. Chem. Phys., 8, 6155-6168, doi:10.5194/acp-8-6155-2008, 2008.
Wong, J. P. S., Lee, A. K. Y., Slowik, J. G., Cziczo, D. J., Leaitch, W. R., Macdonald, A., and Abbatt, J. P. D.: Oxidation of ambient biogenic secondary organic aerosol by hydroxyl radicals: Effects on cloud condensation nuclei activity, Geophys. Res. Lett., 38, L22805, doi:10.1029/2011GL049351, 2011.

Wu, Z., Hu, M., Liu, S., Wehner, B., Bauer, S., Ma Bling, A., Wiedensohler, A., Petäjä, T., Dal Maso, M., and Kulmala, M.: New particle formation in Beijing, China: Statistical analysis of a 1-year data set, J. Geophys. Res.- Atmos., 112, D09209, doi:10.1029/2006JD007406, 2007.

Wu, Z., Hu, M., Lin, P., Liu, S., Wehner, B., and Wiedensohler, A.: Particle number size distribution in the urban atmosphere of Beijing, China, Atmos. Environ., 42, 7967-7980, doi:10.1016/j.atmosenv.2008.06.022, 2008.

Wu, Z. J., Cheng, Y. F., Hu, M., Wehner, B., Sugimoto, N., and Wiedensohler, A.: Dust events in Beijing, China (20042006): comparison of ground-based measurements with columnar integrated observations, Atmos. Chem. Phys., 9, 6915-6932, doi:10.5194/acp-9-6915-2009, 2009.

Wu, Z. J., Nowak, A., Poulain, L., Herrmann, H., and Wiedensohler, A.: Hygroscopic behavior of atmospherically relevant water-soluble carboxylic salts and their influence on the water uptake of ammonium sulfate, Atmos. Chem. Phys., 11, 1261712626, doi:10.5194/acp-11-12617-2011, 2011.

Wu, Z. J., Poulain, L., Henning, S., Dieckmann, K., Birmili, W., Merkel, M., van Pinxteren, D., Spindler, G., Mueller, K., Stratmann, F., Herrmann, H., and Wiedensohler, A.: Relating particle hygroscopicity and $\mathrm{CCN}$ activity to chemical composition during the HCCT-2010 field campaign, Atmos. Chem. Phys., 13, 79837996, doi:10.5194/acp-13-7983-2013, 2013.

Wu, Z. J., Poulain, L., Birmili, W., Größ, J., Niedermeier, N., Wang, Z. B., Herrmann, H., and Wiedensohler, A.: Some insights into the condensing vapors driving new particle growth to $\mathrm{CCN}$ sizes on the basis of hygroscopicity measurements, Atmos. Chem. Phys., 15, 13071-13083, doi:10.5194/acp-15-13071-2015, 2015.

Ye, X., Tang, C., Yin, Z., Chen, J., Ma, Z., Kong, L., Yang, X., Gao, W., and Geng, F.: Hygroscopic growth of urban aerosol particles during the 2009 Mirage-Shanghai Campaign, Atmos. Environ., 64, 263-269, doi:10.1016/j.atmosenv.2012.09.064, 2013.

Yeung, M. C., Lee, B. P., Li, Y. J., and Chan, C. K.: Simultaneous HTDMA and HR-ToF-AMS measurements at the HKUST Supersite in Hong Kong in 2011, J. Geophys. Res.-Atmos., 119, 9864-9883, doi:10.1002/2013JD021146, 2014.

Zdanovskii, B.: Novyi Metod Rascheta Rastvorimostei Elektrolitov v Mnogokomponentnykh Sistema, Zh. Fiz. Khim+, 22, 14781495, 1948.

Zhang, J., Wang, L., Chen, J., Feng, S., Shen, J., and Jiao, L.: Hygroscopicity of ambient submicron particles in urban Hangzhou, China, Front. Environ. Sci. Eng. China, 5, 342-347, doi:10.1007/s11783-011-0358-7, 2011.

Zheng, X., Liu, X., Zhao, F., Duan, F., Yu, T., and Cachier, H.: Seasonal characteristics of biomass burning contribution to Beijing aerosol, Sci. China Ser. B, 48, 481-488, 2005. 